\title{
THE DISTRIBUTION OF BENTHIC FORAMINIFERA IN THE CELTIC SEA: THE SIGNIFICANCE OF SEASONAL STRATIFICATION
}

\author{
Gillian A. Scott, James D. Scourse ${ }^{2}$, AND William E. N. Austin ${ }^{1}$ \\ School of Ocean Sciences, University of Wales (Bangor), Menai Bridge, Anglesey, LL 59 5EY, UK
}

\section{ABSTRACT}

Seasonal stratification is an important phenomenon in tidally-stirred shelf seas, influencing biological productivity, sedimentation rates, the organic content of shelf sediments, and the climate of surrounding landmasses. Previous micropaleontological and stable isotopic investigation investigation of a Holocene sequence from the Celtic Sea suggests that benthic foraminiferal distributions are linked to the physical and biological oceanographic characteristics associated with stratification. We have tested this hypothesis by analyzing the living and dead foraminiferal faunas from surface samples collected during across-frontal cruises during the summers of 1995 and 1996. Foraminiferal and environmental data for 56 samples are presented. Live and dead foraminiferal data were analyzed by factor analysis and, along with the environmental data, canonical correspondence analys is (CCA). Four distinct assemblages were identified from factor analysis of the live data: (1) a frontal assemblage characterized by Stainforthia fusiformis, (2) a mixed water assemblage characterized by Cibicides lobatulus, Textularia bockii, Spiroplectammina wrightii, Ammonia batavus and Quinqueloculina seminulum, (3) a stratified assemblage characterized by Bulimina marginata, Hyalinea balthica, Adercotryma wrighti and Nonionella turgida, and (4) an eastern assemblage dominated by Bulimina gibba, Elphidium excavatum and Eggerelloides scaber. Factor analysis of the dead data reproduces all groupings except the frontal assemblage. These data therefore support interpretations based on earlier stratigraphic data, and highlight the significance of benthic foraminifera as faunal indicators of paleostratification in shelf seas. The distributions also support predicted cross-frontal transfer of nutrients and the existence of surface converging circulation cells. Statistical analyses indicate the significance of unmeasured ecological variables which we speculate might be food supply, and oxygen concentration of bottom and sediment pore waters.

\section{INTRODUCTION}

Although continental shelves account for just $10 \%$ of the ocean flbor area, shelf seas contribute $20 \%$ or more of marine primary production (Walsh, 1988) and are therefore a significant component of the global carbon cycle. Much of this primary production is associated with seasonal stratification and she if sea fronts (Berger and others, 1989). Seasona1 thermal stratification is the dominant hydrodynamic

${ }^{1}$ School of Geography and Geosciences, University of St. Andrew 's, St. Andrew's, Fife, KY16 9ST, Scotland, UK.

${ }^{2}$ Corresponding author, e-mail: j.scourse@bangor.ac.uk phenomenon of tide-dominated she if seas in the middle and high htitudes. Stratification occurs when summer heating of the sea surface exceeds tidal stirring. The resultant fronts, separating mixed from stratified water, are zones of enhanced primary production and support a coupled pelagicbenthic ecosystem which influences organic sedimentation and the production and preservation of microfossils (Fig. 1).

Austin and Scourse (1997) published an AMS ${ }^{14} \mathrm{C}$ dated Holocene benthic foraminiferal stable oxygen and carbon isotopic record from the central Celtic Sea (BGS vibrocore $57 /-07 / 199$ ), which they interpreted as a record of the onset of seasonal stratification during the early Holocene. The isotopic record was associated with changes in benthic foraminifera 1 assemblages in which an early mixed phase (thermocline state I), characterized by an epifaunal assemblage dominated by Cibicides lobatulus and Quinqueloculina seminulum, was progressively replaced (thermocline state II) by an infaunal assemblage dominated by Bulimina marginata in the later stratified phase (thermocline state III). These changes suggested that the foraminiferalassemblages themselves are linked to the plexus of factors defining, or associnted with, stratification.

This paper tests the hypothesis that benthic foraminiferal distributions in the Celic Sea are intimately linked to the physical and biogeochemical processes associated with seasonal stratification. Surface samples colkcted during two cruises during 1995 and 1996 have been analyzed for living and dead foraminiferal faunas and compared with associted environmenta 1 data. Dead assemblages integrate seasona 1 changes in the foraminiferal populations, and time-averaging is therefore a better analogue for interpretation of fossil assemblages than the live assemblages. Furthermore, sediment transport patterns and test preservation are linked to peak bed stress vectors, which are themselves a function of the hydrodynamic regime associated with seasonal stratification (Austin, 1991).

\section{OCEANOGRAPHIC SETTING}

The Celtic Sea extends from the $200 \mathrm{~m}$ isobath in the south and west of the continenta 1 shelf bordering the North Athntic, to southern Ire and and the entrances to the Irish, Bristol, and Eng lish channels (Pugh and Thompson, 1986). The study area is restricted to part of the northern Celtic Sea between $51^{\circ}$ and $52^{\circ} 25^{\prime} \mathrm{N}$ between $4^{\circ}$ and $7^{\circ} \mathrm{W}$ (Fig. 2). The St. George's Channe1 Trough in the southern Irish Sea trends in a NW-SE direction into the extensive and broad Celtic Deep basin, which is included within the study area.

As in all tide-dominated shelf seas, heating of the surface waters in the Celtic Sea induces buoyancy and stability, but the turbulence generated by the action of bottom friction on tidal currents acts against this, and may generate sufficient $\mathrm{k}$ inetic energy to maintain vertical mixing throughout the depth of the water column. During winter, the entire water 


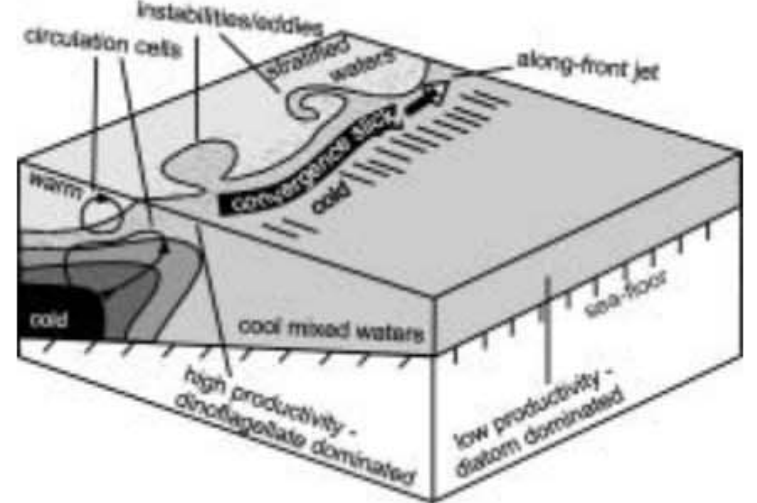

FIGURE 1. Schematic depicting the nature, dynamics, and biology of a tidal front (summer situation). T idal fronts are seasonalphenomena common on high and mid-latitude continental shelves which occur at the juxtaposition of deeper, stratified, waters with shallower, mixed waters. The shallow, mixed, side has uniform temperature and density throughout, intermediate between the surface and bottom characterstics of the stratified side.

column is mixed with re htively uniform temperature, salinity, and density characteristics throughout. In early spring, when heat fluxes from the atmosphere to the sea surface, a warm surface layer develops. This layer is separated from the colder bottom waters by a sharp density gradient, the pycnocline, which restricts the exchange of heat and nutrients between the two water bodies (Fig. 1). In the Celtic Sea, where salinities are generally high throughout, the pycnocline genera lly coincides with the thermocline, defined as the sharp temperature gradient between the surface and bottom waters (E lliott and others, 1991). In autumn, as atmospheric cooling begins, the surface hyer loses heat both upwards and downwards. Eventually the two layers become equal in temperature, the thermocline disintegrates and the whole water column re-mixes. Variations in tida lmixing and water depth result in some areas of the shelf becoming stratified while adjacent waters are mixed; the transition between the two is marked by a strong horizonta1 gradient known as a front.

The main tida 1 front in the study area is the Celtic Sea front extending between Britain and Ireland and curving southwards, at around $51^{\circ} \mathrm{N}$, along the British coast. This front can be recognized in summer by temperature measurements across the boundary area and is recorded by satellite imagery which detects sharp, horizontal surface temperature gradients (Simpson and Bowers, 1979). The mixed zone is confined to the shallower (generally $<100 \mathrm{~m}$ ) inshore waters in the north and east of the study area, whereas the deeper water over the central and outer shelf stratifies during the summer months.

When discussing the biologica 1 oceanography associnted with shelf sea fronts, it is important to distinguish between mixed, frontal, and stratified waters. The 'chssical' phytophnkton cycle for seasonally stratified waters is characterized by a spring blom followed by a subdominant autumn bloom. In winter there are few phytophnkton living because, although there is a high ava ilability of nutrients, individuals are mixed below the euphotic zone and cannot photosynthesize. In spring, light input increases and the

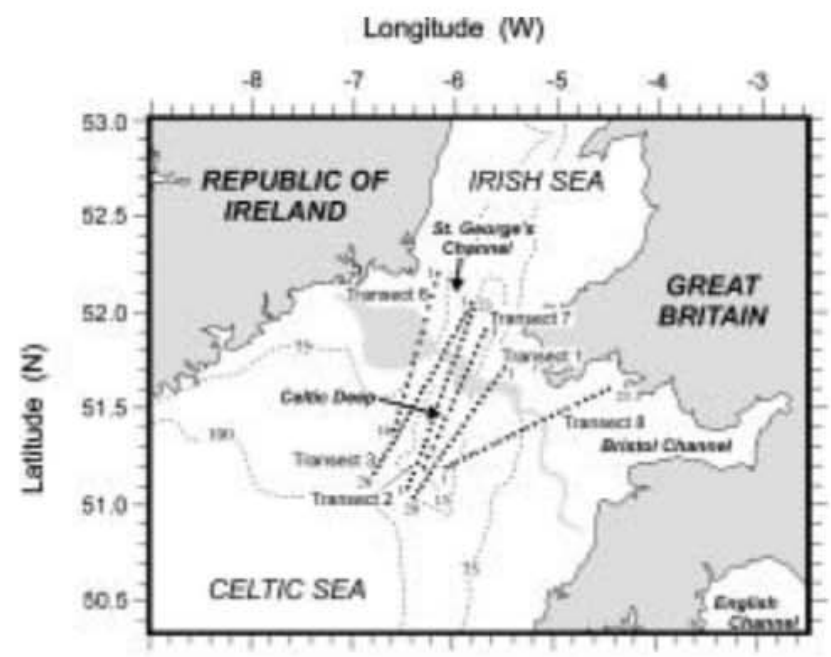

FIGURE 2. Location of study area showing the transects and CTD stations from which foraminiferal sediment, and water samples were collected. Stippled area represents the mean summer position of the Celtic Sea front.

wind-mixed layer shalbws until it no longer exceeds the critical depth (Sverdrup, 1953), the phytoplankton experience high levels of illumination, and a bloom is triggered.

Herbivorous zooplankton and bacteri 1 blooms hg the phyoplankton blooms. Grazing pressure from zoophnkton and the exhaustion of nutrients in the euphotic zone result in a low summer phytoplankton standing stock. The autumn bloom is attributed to a decrease in zooplankton numbers as a consequence of predation and the increased availability of nutrients due to wind-driven mixing. Diatoms comprise the majority of the spring bloom, while the summer population is dominated by dinoflagellates. Those areas characterized by year-round tidal mixing and frontal regions have a different biology. Holligan (1981) observed that fronts mark the landward limit of the spring bloom, which occurs only in stratified waters, while tida lly mixed waters are dominated by relatively low numbers of diatoms. The fronta1 region consists of a bw diversity, dinoflagellate population which has a single summer peak, rather than a biannual bloom, as does the subsurface phytophankton maximum nearest the front (Fig. 1).

\section{MATERIALS AND METHODS}

\section{SAMPLING}

The samples used in this study were collected in the northeast Celtic Sea during two cruises aboard the $R V$ Prince Madog in June-July 1995 and June 1996. Shipek grab samples were collected from 72 stations arranged a bng transects 1,2 and 3 in 1995, and 56 stations along transects 6,7 and 8 in 1996 (Fig. 2). The transects all intersected the Celtic Sea front in approximately a north-south direction except transect 8 which traversed the entrance to the Bristol Channel and the front from approximately west to east. Each Shipek grab sample was subsampled for foraminiferal and grain size analyses and, from transects 1-3, sediment geochemical analyses. Care was taken to ensure that only the surface $(\sim 0.5 \mathrm{~cm})$ of each sample was subsampled. Samples 
for foraminiferal analysis were preserved in ethano1, to which rose Benga 1 sta in was added in order to discriminate between live and dead individuals. Samples for geochemical analysis were frozen. The temperature, salinity and density characteristics of the entire water column were also measured for each station using a NeilBrown Mk IIIb profiling conductivity, temperature and depth probe (CTD).

\section{SEDIMENT ANALYSIS}

The grain size samples were wet sieved through a $63 \mu \mathrm{m}$ mesh and the retained sediment was dried at $105^{\circ} \mathrm{C}$ overnight in preparation for dry sieving. The hrger fractions were sieved at $0.5 \Phi$ interva $\mathbf{s}$ and measured to an accuracy of $0.01 \mathrm{~g}$. A sedigraph (M icromeritics $5000 \mathrm{ET}$ ) was used to measure grains of $<100 \mu \mathrm{m}$ in diameter. Samples were centrifuged with distilled water, treated with $10 \%$ hydrogen peroxide to remove organic matter, and then centrifuged aga in with distilled water. Calgon was used to deflocculate the samples, which were then dispersed in an ultrasonic bath for 15 minutes (Stein, 1985), followed by the use of a magnetic stirrer. The suspended solution was loaded into the sample cell and the X-ray intensity set to 700. Samples were analyzed for sizes between $3-100 \mu \mathrm{m}$ and maintained at $32^{\circ} \mathrm{C}$. Grain size parameters for each sample were calcuhted using a Fortran grain size analysis package (Jones, 1990). These include modal and mean grain size, sorting, skewness and kurtosis for both moments and Folks (Folk, 1966; Folk and Ward, 1957).

\section{GEOCHEMICAL ANAL ySIS}

The samples for geochemical analysis $\left(\mathrm{CaCO}_{3}\right.$, inorganic carbon, organic carbon and nitrogen content) were thawed, sieved through a $500 \mu \mathrm{m}$ sieve to remove the larger fragments, ground until the sediment had the consistency of flour, then weighed. The samples for organic carbon analysis were reacted with $100 \mu 1$ of $\mathrm{HC} 1$ and dried to remove all $\mathrm{CaCO}_{3}$. Samples were then processed by a Carlo Erba NA1500 carbon analyzer (Verardo and others, 1989). Samples were run in batches of up to 50 , inchuding control samples of A cetanilide, a National Bureau of Standards certified standard reference material for organic carbon/nitrogen microchemical analyses. The organic carbon and nitrogen contents were calculated using the data from the analyzer and the a gorithm given in Verardo and others (1989). Inorganic carbon was calculated by subtracting organic carbon from total carbon, which was processed as above but without the decalcification step.

\section{FORAMINIFERAL ANALYSIS}

In preparation for microscopic examination, foraminifera 1 samples were washed through a $63 \mu \mathrm{m}$ sieve and dried overnight. Flotation was carried out according to Meldgaard and Knudsen (1991) using carbon tetrach bride ( $\left.\mathrm{CCl}_{4}\right)$, which is considered appropriate for recent sediments; residues were checked for non-floating tests. A total of 52 samples were picked for 300 living and 300 dead individuals; identifications were based on a number of taxonomic sources (Haynes, 1973; Murray, 1971, 1991, 2000).

\section{Statistical ANALYsis}

Both live and dead foraminiferal data were analyzed using two different multivariate statistical techniques. Factor analysis involved the application of simultaneous Q- and Rmode analysis using a MINITAB program after Walden and Smith (1995). Data were prepared for analysis in the way prescribed by Imbrie and Kipp (1971), and any species which did not comprise at least $8 \%$ of one sample was eliminated before analysis. Data were input in the form of percentages. In addition, Textularia bockii and Spiroplectammina wrightii were grouped under the heading Textilina group because of their taxonomic and ecological affinity (Murray, 1979). All Bolivina, Brizalina and Bolivinella species were summed together into a Bolivina group, and all Reophax species were summed as a Reophax group. The input dataset used for the live factor analysis comprised 22 species or species groups; 13 were used for the dead analysis.

CCA is a useful complement to factor analys is because it examines each species individually and can help expla in non-interactive inter-species associations (CCA does not consider inter-species interactions).

CCA was performed on a data set comprising both foraminiferal and environmenta 1 data and using the program (CANOCO, version 3.12, 1991) after ter Braak (1991). A detrended correspondence analysis (DCA) was automatically performed by CANOCO on the faunal data. In preparation for the analysis, those species which did not constitute $5 \%$ or more of at least one sample were removed from the species dataset. Species were not grouped for canonica1correspondence analys is (CCA) and only those environmenta 1 variables which did not covary significantly were included in the environmental dataset. These included depth, temperature, \% grave1,\% sand, mean grain size, sorting (moments), skewness, and kurtosis (both calculated using moments and Folks), latitude and longitude. Percentage values were used for the species data and absolute numbers for the environmenta 1 data. To determine the exclusive individual contribution of each environmenta1variable to the analysis, a series of parti 1 CCAs were carried out after Borcard and others (1992).

\section{RESULTS}

\section{ENVIRONMENTAL GRADIENTS}

The position of the tidal front was identified using temperature and salinity data from throughout the water column. Though this information is useful with regard to foraminiferal distributions in a qualitative way, for the purposes of the statistical analyses, only the bottom water temperature and salinity measurements were used. These, together with the position, depth, and remaining oceanographic data are given in Table 1.

Changes in bottom water temperatures across the area are shown in $\mathrm{F}$ igure $3 \mathrm{a}$. These range from cooler stratified waters in the south (minimum $8.88^{\circ} \mathrm{C}$ ) to warmer fully mixed conditions in the north (maximum $12.35^{\circ} \mathrm{C}$ ). Isotherms if lustrate that the stratified waters extend further north in the Celic Deep bathymetric trough, suggesting that the subthermocline waters are fixed by depth in this area. Bottom 
TABLE 1. Depth, position, water and sedimentary characteristics of each sampling station.

\begin{tabular}{|c|c|c|c|c|c|c|c|c|c|c|c|}
\hline \multirow[b]{2}{*}{ Sample: } & \multirow{2}{*}{$\begin{array}{c}\text { Depth } \\
(\mathrm{m})\end{array}$} & \multicolumn{2}{|c|}{ Bottom water } & \multirow{2}{*}{$\begin{array}{l}\% \text { Organic } \\
\text { carbon }\end{array}$} & \multirow{2}{*}{$\begin{array}{l}\% \text { Organic } \\
\text { nitrogen }\end{array}$} & \multirow{2}{*}{$\underset{\text { ratio }}{\mathrm{CNN}}$} & \multirow{2}{*}{$\begin{array}{l}\text { Latitude } \\
\mathrm{N}\end{array}$} & \multirow{2}{*}{ Longitude } & \multirow{2}{*}{${ }_{{ }^{n} \mathrm{C}}^{\mathrm{ind}} \mathrm{Cx}$} & \multirow[b]{2}{*}{$\%$ Grave1 } & \multirow[b]{2}{*}{$\%$ Sand } \\
\hline & & Temperature $\left({ }^{n} \mathrm{C}\right)$ & Salinity PSU & & & & & & & & \\
\hline T1S01 & 64 & 12.27 & 34.9 & 1.17 & 0.23 & 5.09 & 51.68 & 5.49 & 0.0042 & 31.5 & 65 \\
\hline $\mathrm{T} 1 \mathrm{~S} 02$ & 67 & 11.95 & 34.97 & 0.31 & 0.06 & 5.17 & 51.65 & 5.56 & 0.1520 & 28.9 & 68.1 \\
\hline $\mathrm{T} 1 \mathrm{~S} 03$ & 68 & 11.49 & 35.01 & 0.24 & 0.04 & 6 & 51.61 & 5.61 & 0.1357 & 11.7 & 87.6 \\
\hline T1S06 & 87 & 10.17 & 35.38 & & & & 51.5 & 5.77 & 0.5088 & 0.2 & 98.3 \\
\hline $\mathrm{T} 1 \mathrm{~S} 07$ & 86 & 10.1 & 35.38 & & & & 51.46 & 5.82 & 0.5491 & 0 & 96.8 \\
\hline T1S09 & 91 & 9.9 & 35.36 & 0.52 & 0.06 & 8.67 & 51.39 & 5.92 & 0.6133 & 0 & 80.6 \\
\hline T1S14 & 103 & 9.61 & 35.36 & 0.86 & 0.1 & 8.6 & 51.22 & 6.16 & 0.6853 & 1.4 & 44.9 \\
\hline T1S17 & 102 & 9.41 & 35.34 & 0.69 & 0.09 & 7.67 & 51.11 & 6.31 & 0.7238 & 1.1 & 65.1 \\
\hline T1S19 & 101 & 9.56 & 35.37 & 0.25 & 0.03 & 8.33 & 51.04 & 6.41 & 0.6797 & 5.8 & 85.7 \\
\hline $\mathrm{T} 2 \mathrm{~S} 01$ & 98 & 9.41 & 35.34 & 0.14 & 0 & & 51.05 & 6.44 & 0.7083 & 2.8 & 96.4 \\
\hline $\mathrm{T} 2 \mathrm{~S} 03$ & 104 & 9.25 & 35.3 & & & & 51.14 & 6.38 & 0.7385 & 0 & 91.8 \\
\hline $\mathrm{T} 2 \mathrm{~S} 07$ & 115 & 9.33 & 35.33 & 1.09 & 0.13 & 8.38 & 51.32 & 6.27 & 0.7220 & 0.1 & 17.1 \\
\hline $\mathrm{T} 2 \mathrm{~S} 11$ & 115 & 9.34 & 35.32 & 0.41 & 0.06 & 6.83 & 51.49 & 6.18 & 0.7354 & 0 & 74.6 \\
\hline $\mathrm{T} 2 \mathrm{~S} 14$ & 115 & 9.73 & 35.21 & 0.34 & 0.04 & 8.5 & 51.63 & 6.1 & 0.6182 & 0 & 99.4 \\
\hline $\mathrm{T} 2 \mathrm{~S} 16$ & 111 & 9.53 & 35.32 & & & & 51.71 & 6.04 & 0.6880 & 6.7 & 92.9 \\
\hline $\mathrm{T} 2 \mathrm{~S} 19$ & 105 & 9.95 & 35.32 & 0.35 & 0.04 & 8.75 & 51.84 & 5.96 & 0.5765 & 11.9 & 84 \\
\hline $\mathrm{T} 2 \mathrm{~S} 20$ & 102 & 9.84 & 35.23 & 0.21 & 0.03 & 7 & 51.88 & 5.93 & 0.4553 & 34.3 & 64.5 \\
\hline $\mathrm{T} 2 \mathrm{~S} 21$ & 105 & 10.65 & 35.12 & 0.13 & 0.03 & 4.33 & 51.93 & 5.9 & 0.2322 & 22.5 & 75.6 \\
\hline $\mathrm{T} 2 \mathrm{~S} 22$ & 93 & 11.58 & 34.89 & 0.45 & 0.06 & 7.5 & 51.97 & 5.87 & 0.0995 & 35.7 & 56.3 \\
\hline $\mathrm{T} 2 \mathrm{~S} 23$ & 95 & 11.61 & 34.91 & 0.27 & 0.03 & 9 & 52 & 5.85 & 0.0360 & 34.6 & 64.6 \\
\hline $\mathrm{T} 3 \mathrm{~S} 01$ & 98 & 11.6 & 34.89 & 0.27 & 0.04 & 6.75 & 51.97 & 5.86 & 0.0546 & 24.3 & 73.6 \\
\hline $\mathrm{T} 3 \mathrm{~S} 03$ & 109 & 10.23 & 35.16 & 0.17 & 0.03 & 5.67 & 51.91 & 5.93 & 0.2821 & 20.3 & 77 \\
\hline T3S05 & 108 & 9.71 & 35.24 & 0.22 & 0 & & 51.84 & 6.01 & 0.6114 & 9.4 & 86.9 \\
\hline $\mathrm{T} 3 \mathrm{~S} 07$ & 115 & 9.69 & 35.27 & 0.15 & 0 & & 51.77 & 6.08 & 0.5847 & 2.1 & 96.9 \\
\hline $\mathrm{T} 3 \mathrm{~S} 10$ & 109 & 9.75 & 35.25 & 0.31 & 0.05 & 6.2 & 51.67 & 6.19 & 0.5419 & 0 & 94.1 \\
\hline T3S11 & 99 & 10.1 & 35.15 & 0.26 & 0.04 & 6.5 & 51.63 & 6.22 & 0.5153 & 0 & 92.6 \\
\hline $\mathrm{T} 3 \mathrm{~S} 13$ & 96 & 9.46 & 35.27 & 0.21 & 0.03 & 7 & 51.57 & 6.29 & 0.7059 & 0 & 95.9 \\
\hline $\mathrm{T} 3 \mathrm{~S} 15$ & 96 & 9.3 & 35.32 & 0.39 & 0.05 & 7.8 & 51.5 & 6.37 & 0.7554 & 0 & 85.5 \\
\hline T3S16 & 101 & 9.32 & 35.32 & 0.35 & 0.06 & 5.83 & 51.46 & 6.4 & 0.7515 & 3.5 & 74 \\
\hline T3S17 & 96 & 9.3 & 35.31 & 0.31 & 0.04 & 7.75 & 51.43 & 6.44 & 0.7432 & 1.8 & 84.2 \\
\hline T3S19 & 88 & 9.38 & 35.27 & 0.27 & 0.04 & 6.75 & 51.36 & 6.51 & 0.7176 & 9.6 & 81.8 \\
\hline T3S23 & 92 & 9.25 & 35.26 & 10.17 & 0.02 & 8.5 & 51.23 & 6.66 & 0.7656 & 3.5 & 92.9 \\
\hline $\mathrm{T} 6 \mathrm{~S} 02$ & 75 & 11.82 & 34.92 & & & & 52.11 & 6.2 & 0.0003 & 31.5 & 68.5 \\
\hline T6S06 & 82 & 11.58 & 34.96 & & & & 51.86 & 6.28 & 0.0842 & 1.1 & 98.9 \\
\hline T6S08 & 71 & 11.02 & 34.96 & & & & 51.77 & 6.32 & 0.2758 & 0.4 & 99.6 \\
\hline $\mathrm{T} 6 \mathrm{~S} 10$ & 71 & 10.28 & 35.05 & & & & 51.66 & 6.37 & 0.3513 & 0.4 & 99.6 \\
\hline $\mathrm{T} 6 \mathrm{~S} 12$ & 81 & 9.09 & 35.22 & & & & 51.42 & 6.47 & 0.6356 & 0 & 97.3 \\
\hline T6S14 & 93 & 8.88 & 35.22 & & & & 51.53 & 6.42 & 0.7231 & 0 & 95.2 \\
\hline T6S16 & 93 & 8.89 & 35.23 & & & & 51.33 & 6.5 & 0.7006 & & \\
\hline $\mathrm{T} 7 \mathrm{~S} 02$ & 111 & 10.68 & 35.13 & & & & 51.84 & 5.74 & 0.2707 & 53.7 & 46.3 \\
\hline T7S06 & 116 & 10.04 & 35.24 & & & & 51.66 & 5.89 & 0.3753 & & \\
\hline $\mathrm{T} 7 \mathrm{~S} 10$ & 110 & 9.73 & 35.25 & & & & 51.5 & 6.03 & 0.5556 & 0 & 95.2 \\
\hline T7S16 & 114 & 9.73 & 35.35 & & & & 51.22 & 6.29 & 0.5962 & 0 & 95.2 \\
\hline T8S01 & 106 & 9.82 & 35.35 & & & & 51.17 & 6.17 & 0.6003 & 0 & 22.8 \\
\hline $\mathrm{T} 8 \mathrm{~S} 02$ & 104 & 9.85 & 35.35 & & & & 51.19 & 6.11 & 0.5813 & 0 & 30.5 \\
\hline T8S05 & 90 & 10.36 & 35.29 & & & & 51.24 & 5.9 & 0.4991 & 0 & 82.8 \\
\hline T8S08 & 82 & 10.49 & 35.24 & & & & 51.29 & 5.69 & 0.4464 & 0 & 96.9 \\
\hline T8S09 & 79 & 10.59 & 35.24 & & & & 51.31 & 5.63 & 0.4411 & 0 & 98.9 \\
\hline T8S10 & 76 & 10.75 & 35.24 & & & & 51.33 & 5.56 & 0.4216 & 0 & 99.5 \\
\hline T8S13 & 71 & 11.05 & 35.17 & & & & 51.39 & 5.32 & 0.1758 & 0.1 & 99.6 \\
\hline T 8 S16 & 64 & 11.46 & 35.02 & & & & 51.44 & 5.08 & 0.1718 & 0 & 81.5 \\
\hline T 8 S20 & 49 & 12.27 & 34.67 & & & & 51.51 & 4.75 & 0.1087 & 0.9 & 99 \\
\hline T 8 S21 & 41 & 12.35 & 34.6 & & & & 51.53 & 4.66 & 0.0993 & 4.5 & 77.7 \\
\hline
\end{tabular}




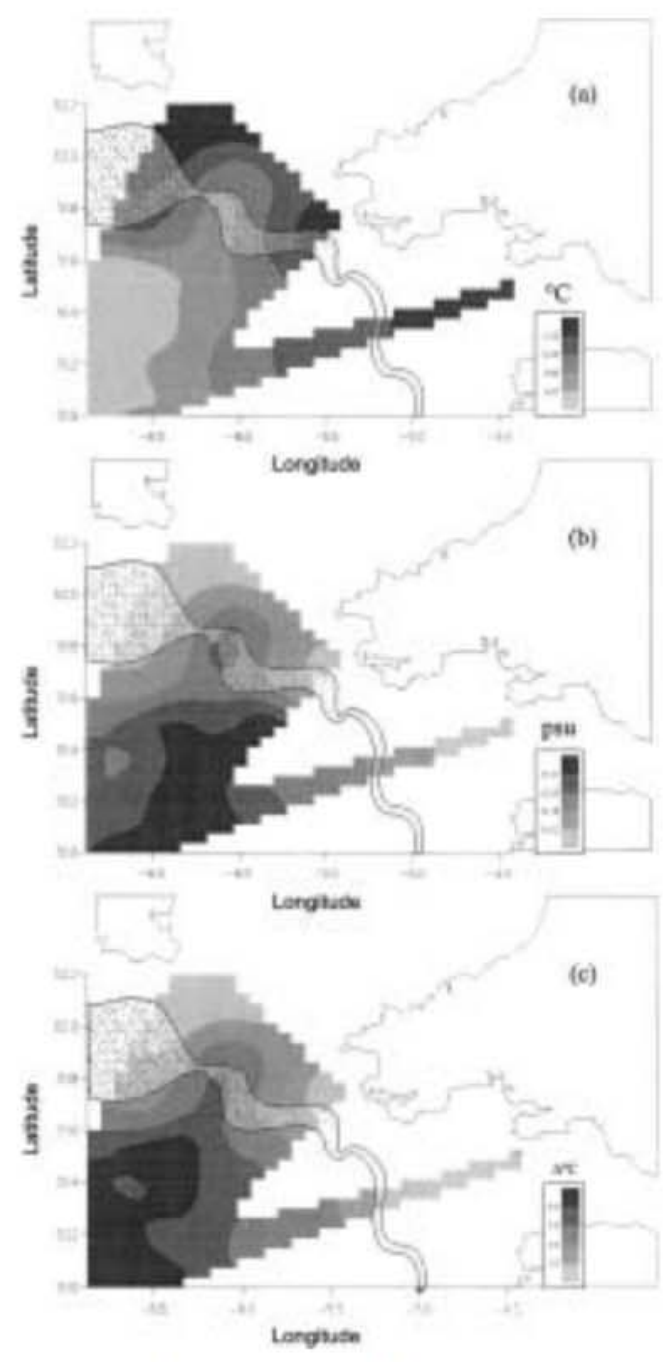

FIGURE 3. Distribution maps of (a) bottom water temperature $\left({ }^{\circ} \mathrm{C}\right)$, (b) bottom water salinity (psu) and (c) stratification index, S-index (surface-bottom water $\Delta^{\circ} \mathrm{C}$ ). Mean summer position of the Celtic Sea front shown.

water salinities are stable across the fronta1region (Fig. 3b), but are lowest in the mixed St. George's Channel waters to the north and in the Bristol Channel, and higher in stratified waters.

Since no single variable provides a measure of the degree of stratification at a sing $\mathbf{k}$ site, the term "S-index" is defined here as the difference between bottom and surface water temperatures $\left(\Delta^{\circ} \mathrm{C}\right)$. The variability of $\mathrm{S}$-index across the area is shown in Figure $3 \mathrm{c}$. Mixed sites are those with $\mathrm{S}$ index values less than 2 and stratified sites are those with an $\mathrm{S}$-index greater than 6 . Intermediate values indicate that a site is frontal.

The percentages of grave 1 , sand, silt and chy were determined for each sediment sample (Table 1). The distribution of $\%$ sand $(>63 \mu \mathrm{m})$ is shown in Figure 4a. This demonstrates that the coarsest sediments lie in the north and northwest, while the finest lie to the south-east and at the end of transect 8 . The relative contribution of grave 1 is highest in the mixed areas to the north, decreasing markedly through
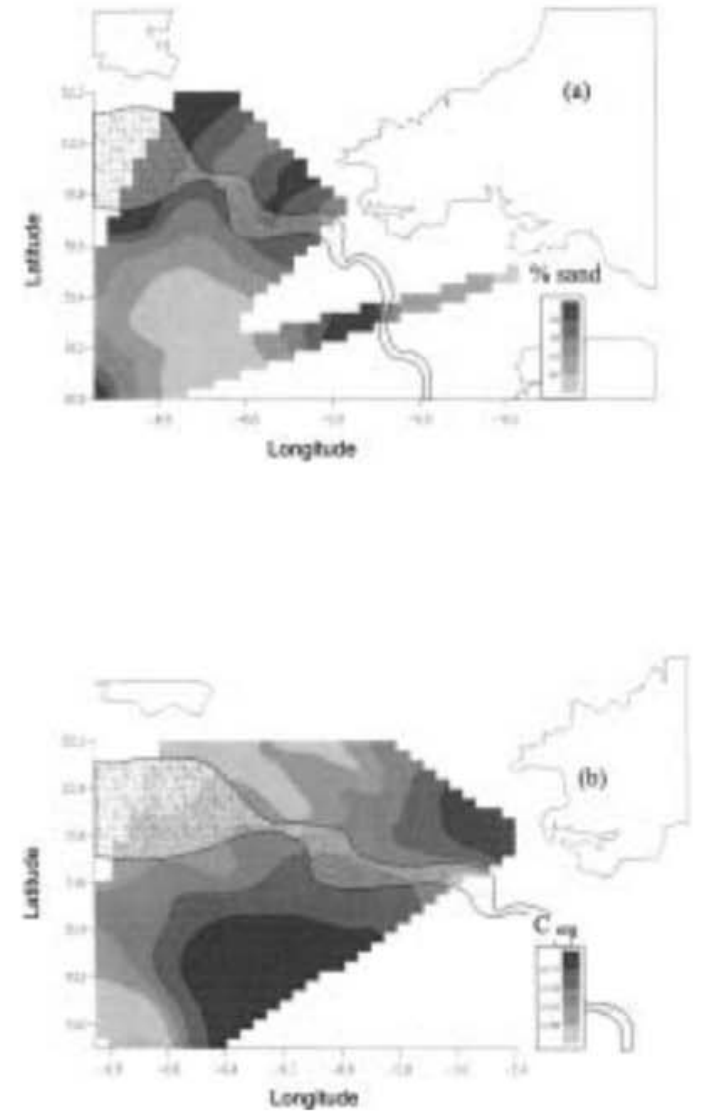

FIGURE 4. Distribution maps of (a) $\%$ sand, (b) $\% \mathrm{C}_{\text {org. }} \cdot \mathrm{C}_{\text {org }}$ data are not available for transect 8 . Mean summer position of the Celtic Sea front shown.

the frontal region. No grave 1 was recorded anywhere a bng transect 8 , but there is a small increase in gravel content to the southwest. Sand content, by contrast, is relatively low in the mixed area to the north, high in the mid-frontal region, and highest in the west.

The distribution of organic carbon (Fig. 4b) demonstrates that surface water productivity, which is concentrated in the fronta 1 zone (Tett and others, 1993) is not directly reflected in the underlying sediments. Other studies have indicated a direct coupling between chlorophyll maxima and organic carbon content of sediments in shelf settings (van Haren and Joordens, 1990). There is, instead, an east-west gradient, possibly due to advection of benthic fhuff into deeper, more quiescent, basins. The inverse relationship in the distribution of organic carbon and \% sand (Fig. 4) lends support to this hypothesis.

\section{FORAMINIFERAL DISTRIBUTIONS}

The percentage contribution of each species to both live and dead assemblages, and the densities of live and dead foraminifera per $10 \mathrm{~cm}^{3}$ of sediment, are given in Appendices I and II. The tota 1 live and dead density distributions are shown in Figure 5 and for individual species in Figure 6. The greatest densities of live foraminifera occur in the area where mixed and fronta 1 waters meet, and in stratified waters lying just beyond the fronta 1 region. Stations a bng 

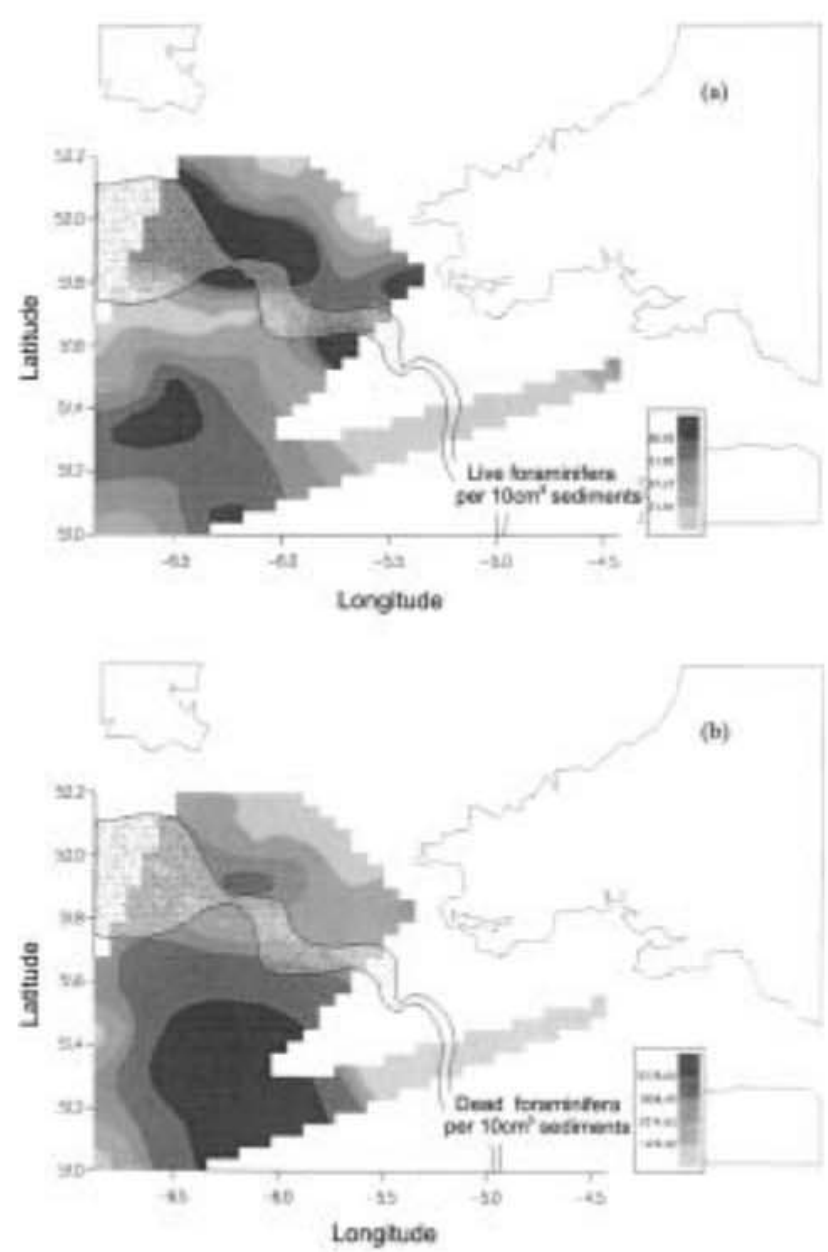

FIGURE 5. Distribution (in numbers of foraminifera per $10 \mathrm{~cm}^{3}$ sediment) of (a) live, and (b) dead foraminiferal densities. Mean summer position of the Celtic Sea front shown

the entrance to the Bristo1 Channe1, in mixed waters, and in the mid-fronta 1 region show the lowest live densitis.

As expected, the dead densities are up to 200 times greater than the live, but the live and dead distributions differ. The greatest dead densities are found in the Celtic Deep basin to the southeast; density decreases with increasing distance from this basin. The live data reflect only a "snapshot" of the foraminiferal distributions during summer conditions, and likely vary seasonally in response to factors such as the spring and autumn blooms. However, the dead distribution shows a strong inverse relationship to gra in size $\%>63 \mu \mathrm{m}$ (Fig. 4a) suggesting that the difference between live and dead distributions might be controlkd by sediment transport. Detailed comments on the distributions of individua1 species are included in Appendix III.

\section{Mul tIVARIATE STATISTICAL ANALySES}

\section{Factor Analysis}

The results of the R-mode analysis on the live data determine the characteristic species of each assemblage, whik the Q-mode scores indicate the significance of each factor at each site. These scores have been mapped to show the area over which each assemblage is important (Fig. 7). The Q-mode scores have a ko been plotted against the measured environmenta 1 variabls at the same sites to examine possible relationships; a derived factor is more likely to exhibit a relationship than any individual scores a bne (Conradsen, 1993). Detailed comments on the factor analysis results of both live and dead datasets are included in Appendix IV. The distributions of the first four factor scores for the dead data, which account for over $84 \%$ of the total variance, are shown in $\mathrm{F}$ igure 8.

\section{Canonical Correspondence Analysis}

The summarized results of the CCA analysis of the live data are presented in Table 2. The sum of the unconstrained e igenvalues is the sum of the lengths of the maximized spread of species along hypothetical environmental gradients, and is effectively a detrended correspondence analysis (DCA; Hill and Gauch, 1980), while the sum of the canonical or constrained eigenvalues is the sum of a maximized spread abng an environmental gradient, which is a linear combination of the measured environmental varibles. By comparing the two, it is possible to ascerta in how well the measured environmental variables expla in the data. Given that the sum of the CCA e igenvalues is only two-fifths of the sum of the DCA eigenvahes, it is very likely that the most important controlling environmenta 1variables were not measured. Only $\sim 30 \%$ of the species data are explained by the measured environmental variables on the first three axes. The first and second axes are almost equally significant, the first exphining $12.6 \%$ of the variance, the second $11.1 \%$. The third axis explains just $5.2 \%$ and the fourth only $3.1 \%$. Only the first three axes are considered further.

To determine the exclusive individual contribution of each environmental varible to the analysis, a series of partia 1CCAs were undertaken (Borcard and others, 1992; Table 3 ). The percentage contribution can be calcuhted by comparing the eigenvalue of the partial CCA with the sum of the values of the main CCA. The contribution made by a particular variable may be greater than that shown because it covaries with other variables. This analysis indicates that the most significant individual contributions are made by latitude, depth, and longitude; i.e., location. Since these variables cannot, in themselves, be responsible for controlling species' distribution, it is clear that they are acting in this analysis as proxies for the true controlling parameters.

The environmenta 1 species, and site scores produced in this analysis are given in Appendix V. The values for the first three axes have been converted to co-ordinates for biplots (Fig. 9). The environmenta 1 variables are represented by arrows whose length approximates their relative signifcance, and whose orientation reflects their relations with the explanatory axes, each other, the sites, and species. Since axes 1 and 2 explain similar amounts of the species variance they are comparable in length. Axis 3 , however, is only half as important as axi 2 . These demonstrate that the first axis is hrgely a function of mean grain size, skewness, htitude, and $\%$ gravel; the second axi , temperature, depth and longitude; and the third axis, \% sand and sorting. Species are spread a bng the environmental gradients of which mean grain size and \% grave1, temperature, and depth are the most 
important. Species such as Trochammina sp., Globotrochamminopsis pygmaeus, Deuterammina (Lepidodeuterammina) ochracea, Gavelinopsis praegeri, C. lobatulus, and $C$. fletcheri occur optimally in northern sites with hrge proportions of grave1, while species such as Stainforthia fusiformis are found in much finer grained, southerly, sites. Nonionella turgida, Bulimina marginata, Adercotryma wrighti and Hyalinea balthica characterize cold, deep, southerly sites while $Q$. seminulum, $S$. wrightii and $L a-$ marckina haliotidea prefer warmer sites. Bulimina gibba and Eggerelloides scaber show affinity for high \% sand content.

The results of the analysis of the dead assemblage data are presented in Appendix VI and Table 4. Comparison of the sum of the canonical values with the constrained eigenvalues demonstrates that half of the varince can be exphined by the measured environmental varibles. While this is $\mathbf{b w}$, it does mean that these measured parameters are better at explaining the distribution of dead tests than the live. Only $41.4 \%$ of the variance is explained by the first four axes. The first and second axes expla in similar amounts of the variance (16.7 and $12.3 \%$ respectively), while the third explains $10 \%$. Since the fourth axis explains only $3 \%$, only the first three axes are considered further.

Partia1 CCA analysis (Table 5) demonstrates that, as for the live, over half the exphined varince is determined by covarince of the variables. Individually, the most important variable is latitude, but longitude, and skewness measured by moments are also important. The significance of htitude and longitude again suggests that these variables are acting as partial proxies, at least, for the actual environmental controls. The scores produced by the analysis for sites, species, and environmental varibles are plotted in Figure 10. It is clear that depth, temperature, longitude, and latitude are the most significant explanatory variables. Depth and longitude inftuence the first axis, while $\%$ grave 1 , temperature, htitude and mean grain size inftuence the second. The third is a function of $\%$ sand and sorting.

Examination of the position of the various species relative to these gradients demonstrates some clear patterns (F ig. 10). Severa1 species are arranged along the temperature gradient, from $H$. balthica, which characterizes the coldest temperatures, through B. marginata, A. wrighti, G. praegeri, $Q$. seminulum to Elphidium magellanicum. These species are also arranged along a gradient of increasing depth and decreasing grain size. Latitude, grain size, and \% grave 1 all appear to be closely interrelated, and species such as Gaudyrina rudis and Eponides repandus have maxima in the most northerly, coarsest conditions, closely followed by $C$. lobatulus, C. fletcheri and Ammonia batavus. B. gibba and E. scaber reach optima in very high percentages of sand, while the Bolivina group prefers much finer substrates. Species arranged along the depth gradient include $S$. fusiform is in the deepest conditions, through $S$. wrightii, T. bockii, $Q$. seminulum, Miliolinella subrotunda to Elphidium excavatum in the shallowest.

The first axes of the both the living and dead analyses were subject to Monte Carb permutations to test for significance. Both produced P-values of 0.01 , demonstrating that these axes were significant.

\section{DISCUSSION}

Temperature and salinity measurements taken across the front in June-July 1995 and June 1996 record strong, temperature-driven, stratification in the Celtic Sea. The front marks the separation of mixed and stratified, cold and warm waters, high and low energy tidal currents, and is associted with high kve $\mathbf{s}$ of productivity. It is known that these oceanographic features remain in place from mid-March to late-September (E lliott and others, 1991).

Though upwelling and downwelling resulting from alongfront flows are difficult to measure (Hill and others, 1993), they are believed to profoundly influence productivity (James, 1978; Savidge and Foster, 1978). The weak circulation cells depicted in Figure 1 suggest that the seabed in the frontal region does not rece ive equal rates of debris and carbon flux from above (K. Horsburgh, pers. comm. 1999). It is likely, though unproven, that while the area directly beneath the convergence slick receives flux from above, some of the particulate matter becomes entrained by the flow between the circulation cells and is delivered instead southwards to the stratified area beyond the front. The seabed separating these two zones of deposition is, by contrast, deprived of detritus which is drawn away by the same flows.

The distribution map for organic carbon in the Celtic Sea (Fig. 4b) indicates that there is indeed a strong degree of pelagic-benthic decoupling between the surface waters and the seabed. Since productivity is centered around the fronta 1 region, it might be expected that this would be reflected in the beneath-front seabed sediments. Instead, there is a clear east-west gradient which probably results from the redistribution of organic materi 1 to more quiescent areas. This interpretation is supported by the inverse relationship with $\%$ sand $(\mathrm{Fig}$. 4a). The coarsest grain sizes are found in the north and the finest in the south, apart from a patch of coarse sediments in the extreme southwest. The hydrographic data, particularly temperature, accurately reflects the strength and distribution of stratification in the northeast Celtic Sea, but does not directly record the associnted stratification dynamics which have been derived by other workers (cf. Hill and others, 1993). The sedimentary regime is clearly profoundly

FIGURE 6. Distributions, in \% frequency total live and \% frequency total dead foraminifera, of (a) live Ammonia batavus, (b) dead $A$. batavus, (c) live Adercotryma wrighti, (d) dead A. wrighti, (e) live Bulimina gibba, (f) dead B. gibba, (g) live Bulimina marginata, (h) dead B. marginata, (i) live Cibicides lobatulus, (j) dead C. lobatulus, (k) live Gavelinopsis praegeri, (1) dead $G$. praegeri, (m) live Hyalinea balthica, (n) dead $H$. balthica, (o) live Nonionella turgida, (p) dead $N$. turgida, (q) live Quinqueloculina seminulum, (r) dead $Q$. seminulum, (s) live Stainforthia fusiform is, (t) dead S. fusiformis, (u) live Spiroplectammina wrightii, (v) dead S. wrightii, (w) live Textularia bockï, (x) dead T. bockï. Contours represent $1 \%, 5 \%, 10 \%$ and increments of $10 \%$ thereafter. These contour intervals are within the errors for the samples point counted for stations shown as black dots (e.g., Galehouse, 1971). Stations with low totals which raised the errors on the data above the $1 \%$ leve 1 for species with low $\%$ frequencies have been excluded from the analysis. Mean summer position of the Celtic Sea front shown. 


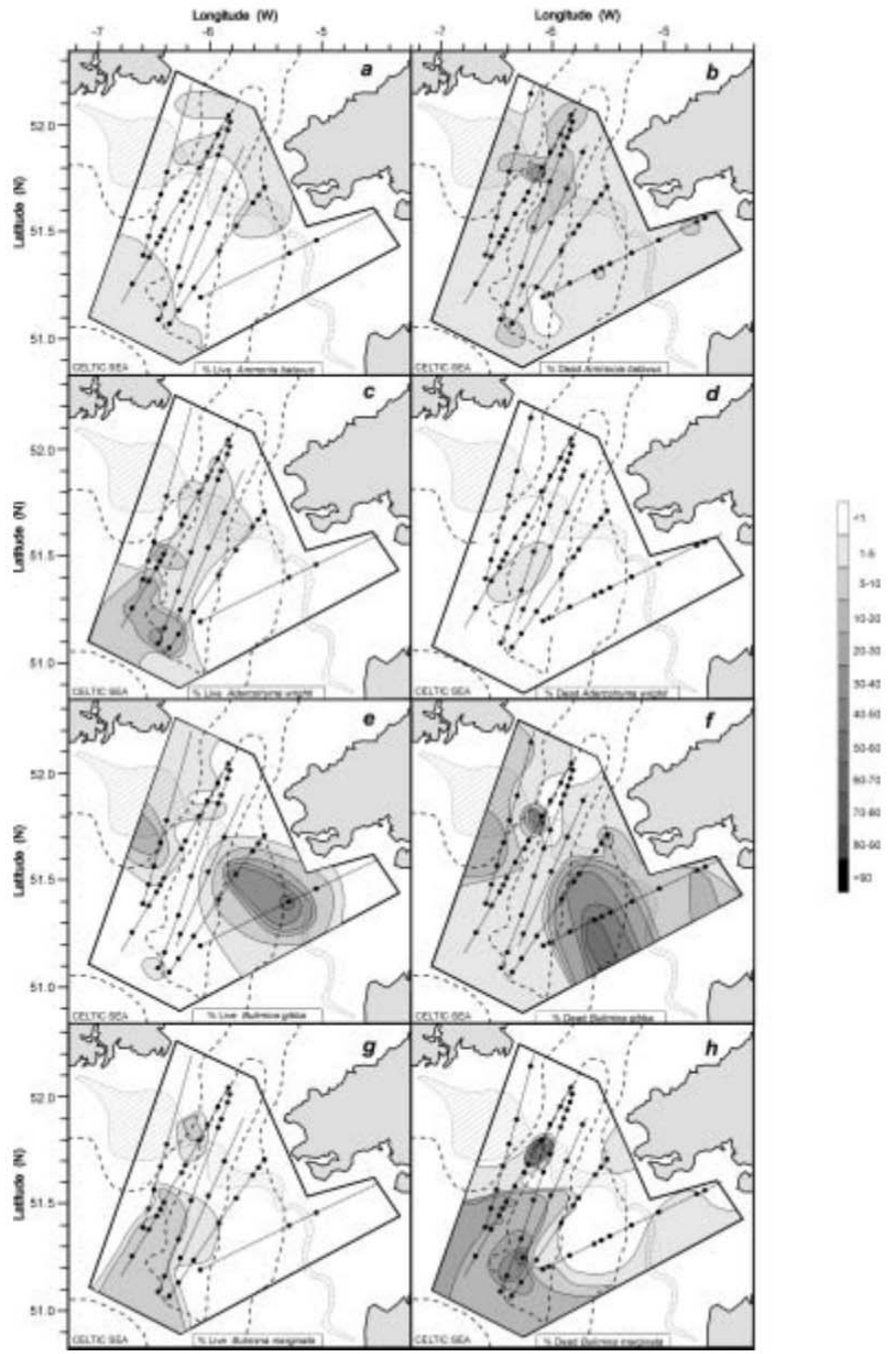




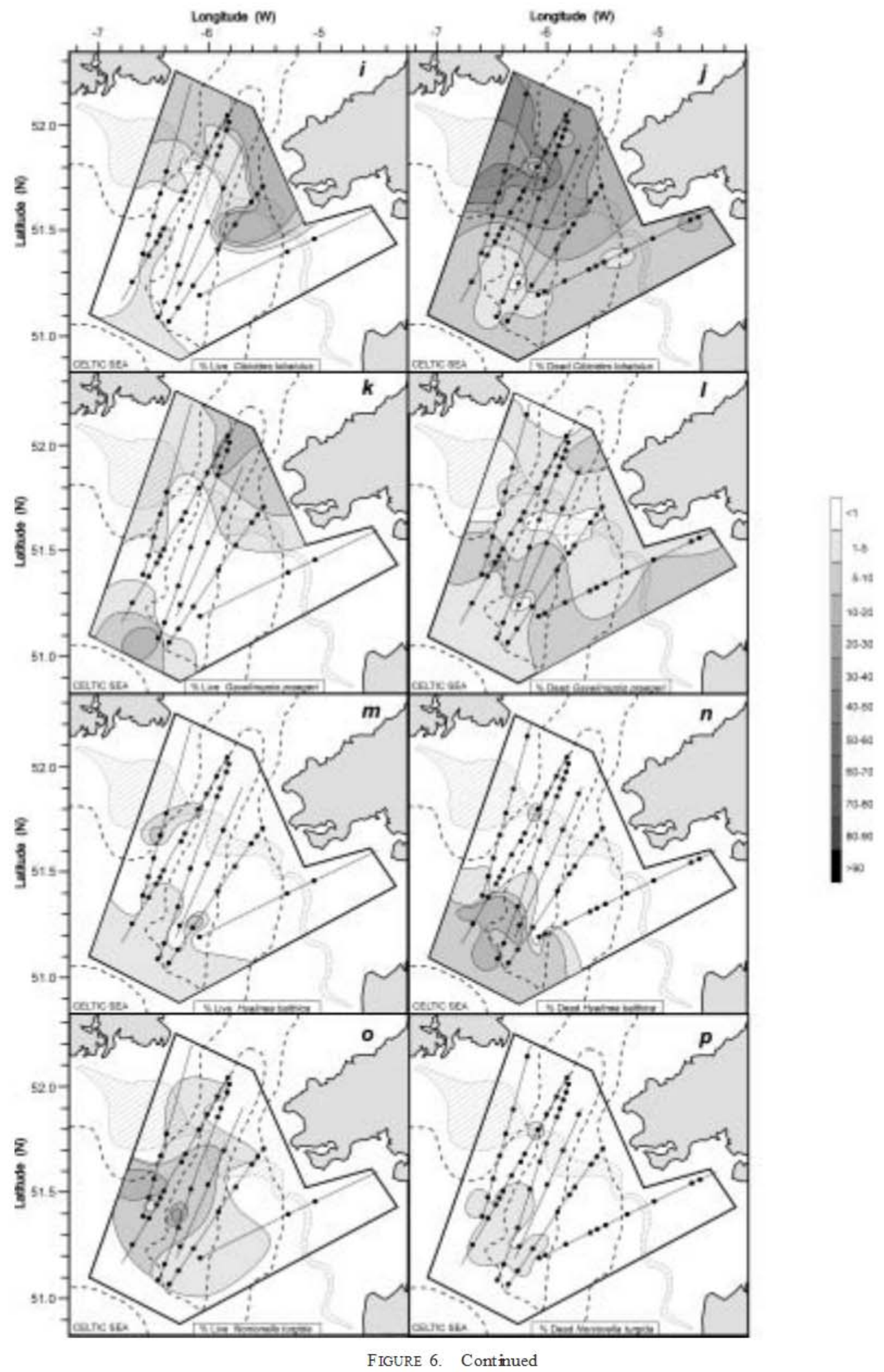




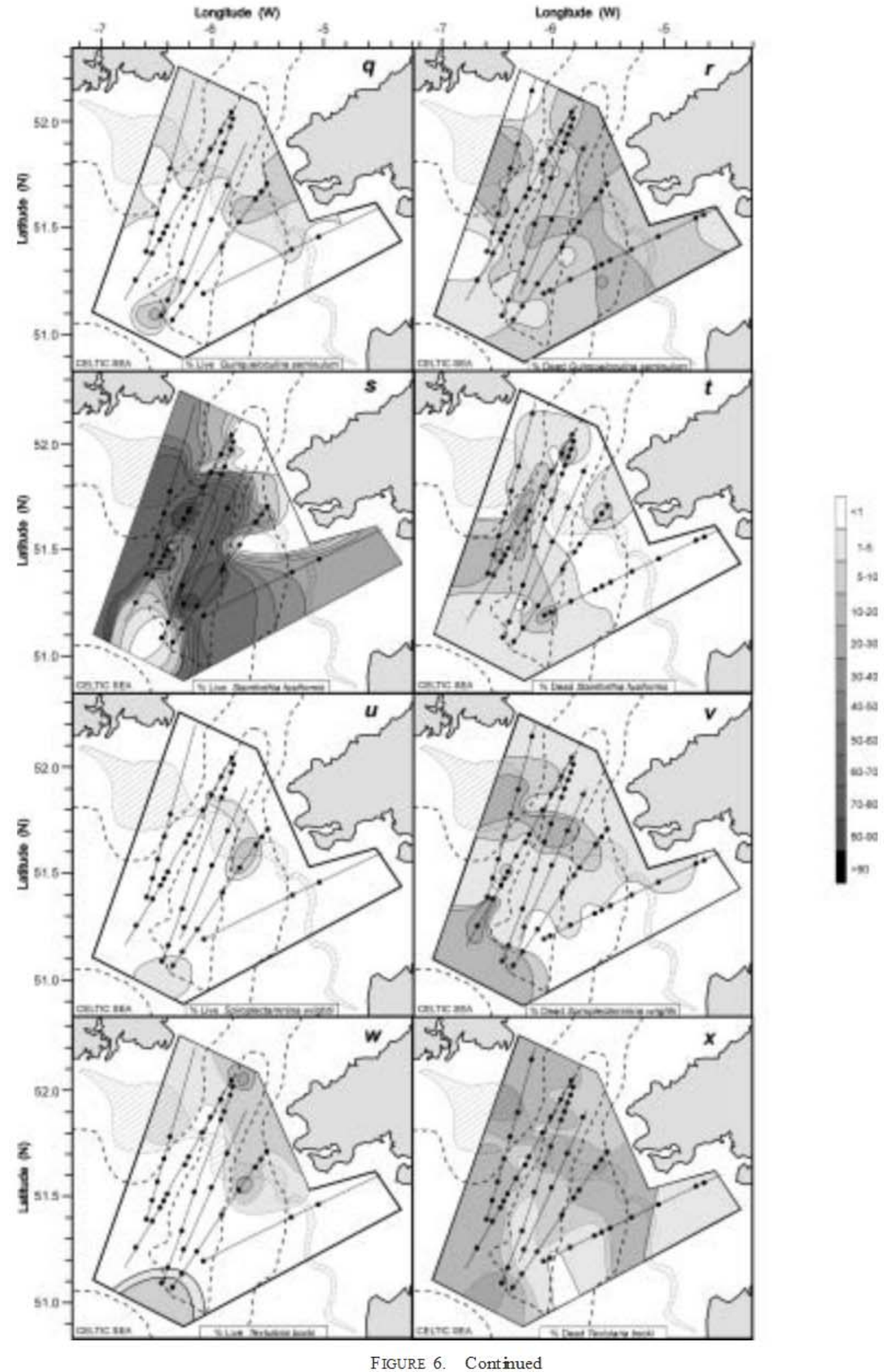



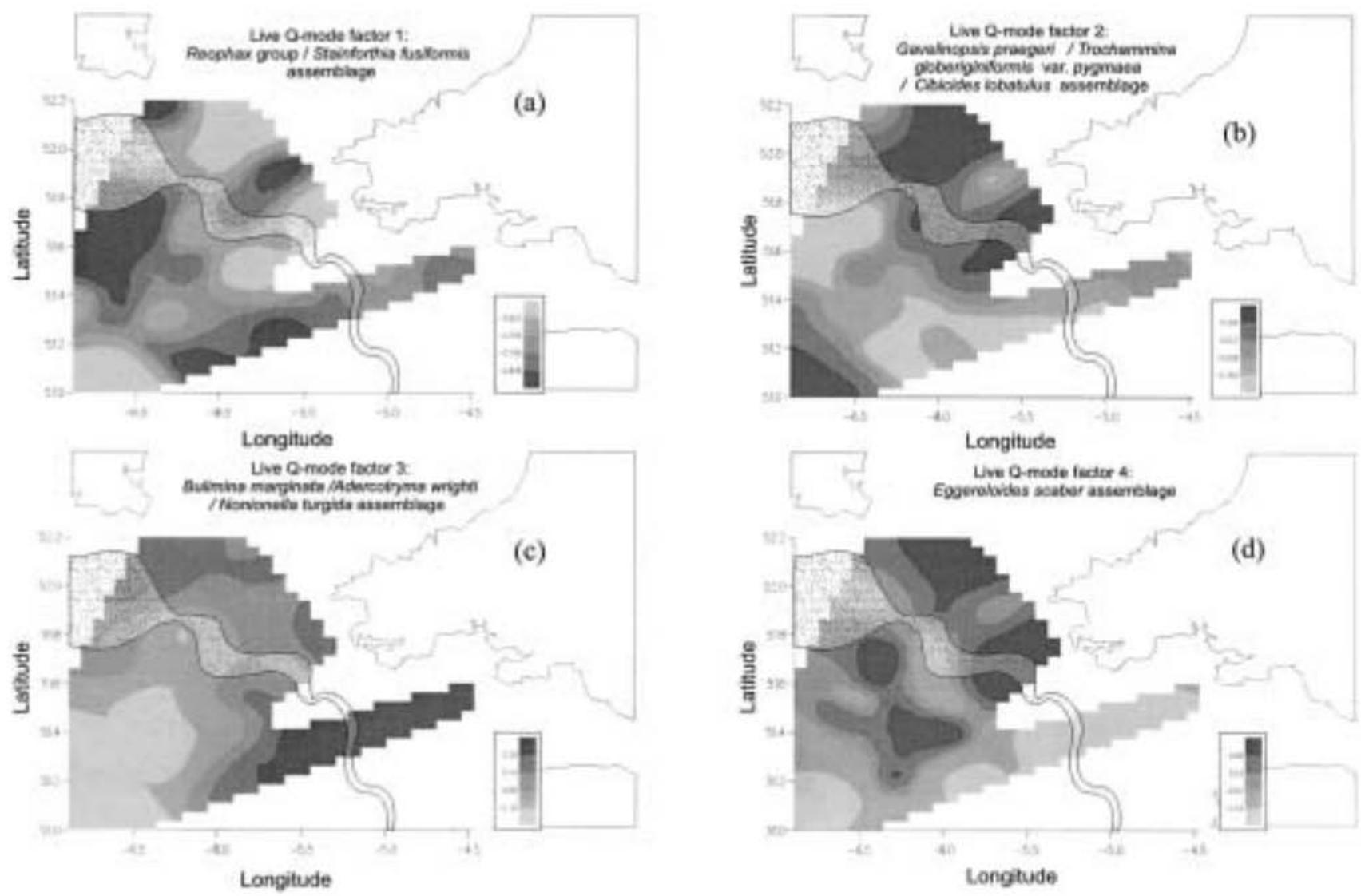

FIGURE 7. The mapped live Q-mode factor analysis scores for (a) factor $1:$ Reophax group and $S$. fusiformis assemblage, (b) factor $2: G$. praegeri, T. globeriginiformis var, pygmaea and C. lobatulus assemblage, (c) factor 3:B. marginata, A. wrighti and $N$. turgida assemblage, (d) factor 4: $E$. scaber assemblage. Mean summer position of the Celtic Sea front shown.

influenced by the bcal oceanography, but the relationship is complex, and subject to reworking. Most significantly, the precise condition of the water column structure is not registered in the sediments directly beneath.

There are large differences between the live and dead distributions of some species (Fig. 6). This must be due e ither to the unrepresentative nature of the live distribution at the time of collection, or to post-mortem advection and differential test destruction. Variables such as grain size, sorting, and skewness which, like reworking, are a function of bed stress, have been measured, and so it should be possible to assess when reworking has infuenced the distribution of a particular species. Though reworking is particularly vigorous in shelf environments, it seems reasonable, in this setting characterized by large seasonal varibility, to specuhte that some species' live distributions were not typical of the rest of the year, peak production being triggered by different environmental conditions. Other living/dead differences are a function of production and preservation (Bo1tovsky, 1991; Boltovsky and Totah, 1992; Loubere and others, 1993).

Initial comparison of the live and dead densities ( $\mathrm{F}$ ig. 5) suggests active reworking, since the highest live densities are found in the region of the front whereas the dead are focused into the bathymetric basin in the southwest. The high live densities in the fronta 1 region probably results from the high organic flux associated with the front (e.g., Altenbach and Sarnthein, 1989). However, the individual species' distributions demonstrate that, for the majority of the most significant species, the hydrographic conditions of the area, particularly those during summer stratification, are consistently recorded. This supports Sturrock and Murray (1981), who found that Celtic Sea sediments consist of less reworked material than those in the western approaches to the English Channe1 It is significant that species such as $S$. fusiformis and $N$. turgida, whik constituting only a fraction of the dead assemblages, are neverthe less very significant indicators of frontal and stratified conditions respectively.

Factor analysis identifies a number of distinctive assembhges associnted with the hydrographic conditions. These assemblages provide powerful tool for reconstructing the long-term dynamiss of seasonal stratification. The mixed and mixed-fronta 1 sites are typically dominated by dead tests of $C$. lobatulus, T. bockii, S. wrightii, A. batavus and $Q$. seminulum. Of these, only C. lobatulus is typical of a live mixed assemblage, which corre htes with coarser sediments. Stratified and stratified-frontal waters are characterized by B. marginata, $H$. balthica, Bolivina group, A. wrighti and $N$. turgida. Factor analysis a so suggests that $G$. praegeri should also be included in this group. However, the live distribution of $G$. praegeri shows that this species actually lives in mixed waters (F ig. $6 \mathrm{k}, \mathrm{D}$ ) so its inchsion in this 

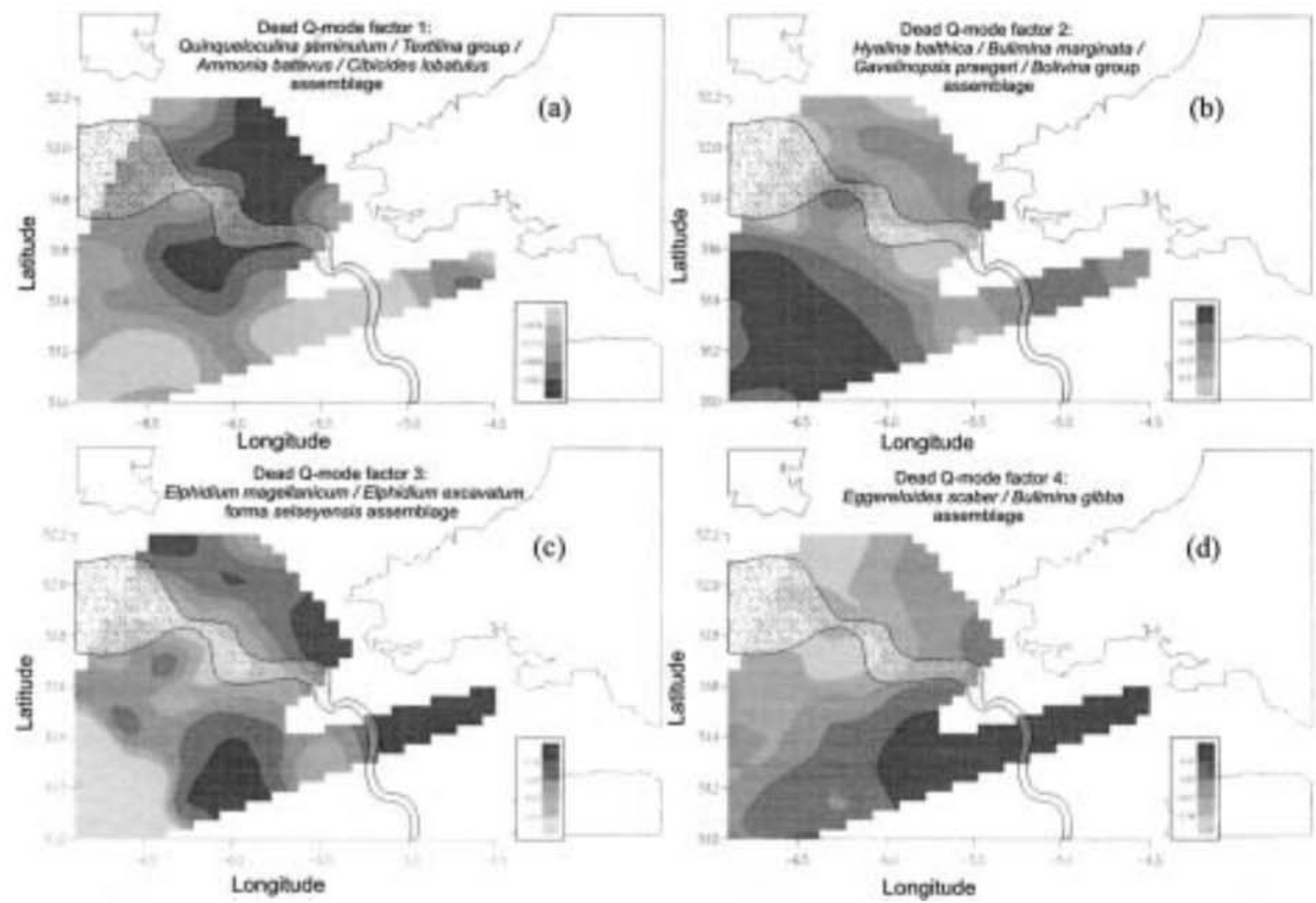

FIGURE 8. The mapped dead Q-mode factor analysis scores for (a) factor 1: $Q$. seminulum, Textilina group, A. batavus and $C$. lobatulus assemblage, (b) factor 2: H. balthica, B. marginata, G. praegeri and Bolivina group assemblage, (c) factor $3:$ E. magellanicum and E. excavatum forma selseyensis assemblage, (d) factor $4: E$. scaber and $B$. gibba assemblage. Mean summer position of the Celtic Sea front shown

group is probably a function of reworking. Precisely why this species should be so thoroughly decoupled from mixed waters, when a concave epifaunal species such as C. lobatulus is not, is difficult to exphin; the hydrodynamic properties of the infhted $G$. praegeri test may be partly responsible. N. turgida and $A$. wrighti are included in this group, despite the ir rarity in the dead assemblages, because they are so firmly related to stratification. The area beneath the pervasive eddy in the north Celtic Deep (F ig. $8 \mathrm{~b}$ ) is also dominated by this assemblage, indicating that the regular incursion of stratified waters into the predominantly mixed area is being registered by the foraminiferal assembhges. The correlation of the live assemblage with temperature, salinity, S-index, and longitude show very clearly that this assemblage is directly related to stratification.

Factor analysis indicates that $S$. fusiformis and the Reophax group live in direct association with the front. This relationship was not established for the dead assemblages, however, because ne ther species preserves well, the former being underrepresented and the latter very rare. However, direct explanations for the association of both $S$. fusiform is and Reophax group with the front were not identified by statistical analysis; it is very clear from the poor correlations of several of the factor-derived assemblages with the measured environmental variables, and a so from comparison of the magnitude of varibility explained by unconstrained re1ative to constrained $\mathrm{CA}$, that the main environmental controls were not directly measured. These missing variables may be oxygen concentration and food supply (cf. Nees, 1998). For commonly infauna 1 species like $S$. fusiformis, it is probable that it is the oxygen content of sediment pore waters rather than bottom water which is critical. Alve and Murray (1997), Cara p (1998), and Nees (1998) a loo suggest that the lability and nature of the food supply are significant.

TABLE 2. Summary of the CCA performed on the live data.

\begin{tabular}{|c|c|c|c|c|c|}
\hline Axes & 1 & 2 & 3 & 4 & Total nertia \\
\hline Eigenvalues & 0.31 & 0.28 & 0.13 & 0.07 & 2.48 \\
\hline Species-environment correlations & 0.82 & 0.85 & 0.78 & 0.73 & \\
\hline Cumulative percentage variance of species data: & 12.6 & 23.7 & 28.9 & 32 & \\
\hline Cumulative percentage variance of species-environment relation: & 32.7 & 61.4 & 74.8 & 82.8 & \\
\hline Sum of all unc onstrained eigenvahes (DCA) & & & & & 2.48 \\
\hline Sum of all canonical eigenvahes (CCA) & & & & & 0.96 \\
\hline
\end{tabular}


TABLE 3. Results of the partialCCA performed on the live data.

\begin{tabular}{|c|c|c|}
\hline Environmenta1 variable & $\begin{array}{c}\text { Sum of } \\
\text { eigenvalues } \\
\text { of partia } 1 \mathrm{CCA}\end{array}$ & $\begin{array}{l}\% \text { of the total } 1 \\
\text { explained variance } \\
\text { exchusively } \\
\text { explained by the } \\
\text { environmenta } 1 \\
\text { variable }\end{array}$ \\
\hline depth & 0.05 & 5.85 \\
\hline temperature & 0.04 & 4.91 \\
\hline$\%$ grave1 & 0.04 & 4.18 \\
\hline$\%$ sand & 0.04 & 4.18 \\
\hline mean & 0.03 & 3.44 \\
\hline sorting & 0.04 & 4.38 \\
\hline skew m & 0.01 & 1.98 \\
\hline skew $\mathrm{f}$ & 0.02 & 2.51 \\
\hline kurt m & 0.02 & 2.71 \\
\hline kurt $\mathrm{f}$ & 0.02 & 2.3 \\
\hline latitude & 0.05 & 6.05 \\
\hline longitude & 0.04 & 5.11 \\
\hline Sum of CCA eigenvahes & 0.96 & \\
\hline Covariance & & 52.4 \\
\hline
\end{tabular}

Nees (1998) identified three main food categories: fluffy aggregates which are easy to digest and produced during blooms (Jones and others, 1998); fecal pellets which are less nutrient-rich; and marine snow or particulate organic matter (POM), which is rained constantly but in small amounts. It is reasonable to assume that this full range of food types would be avaihble across a frontal zone given the variability of the associated biology. The mixed waters are turbulent and well-oxygenated and are likely to contain a heavy suspended POM load with a strong lateral component. The frontal region is probably less well-ventilated and characterized by fhuffy aggregates since bloom conditions occur here throughout the summer. The fully stratified region will at least for the htter half of the summer, be poorly oxygenated and have a steady flux of POM. However, where the thermocline is shallow, dinoflagellates thrive, producing fuffly aggregates for at least part of the summer. During the winter months, fully mixed well-oxygenated conditions prevail in the area occupied by stratified water in the summer.

It is apparent that the effects of circulation ce lls have been recorded in the live data, in particular the S. fusiformisReophax group assemblage (live factor 1 ; Fig. 7a), which dominates in the mixed-frontal and the stratified-frontal transitional regions. These regions are separated by a low abundance "shadow", exactly as predicted for organic flux by cross-fronta 1 circulation models. Perhaps even more significantly, the live density data (Fig. 5a) show a very similar pattern.

S. fusiformis is the most abundant live species in this area, appearing in almost every sample counted and constituting up to $66 \%$ live at some sites. It is not nearly as well represented in the dead assemblages though it reaches over $20 \%$ of the dead assemblage at some sites. There are some differences between the distribution of live and dead tests (Fig. 6s,t) but the broad features are similar: a heavy concentration of tests in the area of fronta 1 and frontal-stratified transitional waters, and an absence along the Bristo1Channel and in the fully stratified waters to the south.

The CCA results demonstrate that, when live, this species occurs in greatest abundances in we ll-sorted sediments, skewed towards fines and with bw $\%$ sand content. Its dead distribution is linked to sorting and depth, which suggests reworking. Many workers have reported this species from fine-grained sediments (Collison, 1980; Conradsen, 1993). Murray $(1983,1986)$ also records a discrepancy between live and dead distributions in Lyme Bay. However, S. fusiformis is most offen observed living in association with high leve $\mathbf{s}$ of organic matter (e.g., A lve, 1990, 1994; Alve and Murray, 1997; and Conradsen, 1993). This suggests that the assocition of $S$. fusiformis with muddy sediments may instead be a function of its affinity for organic matter, since these two parameters are linked (Cato, 1977). Thi is supported by the observation that it is not restricted to muddy habitats in the Celtic Sea, occurring also at some of the sandier sites which nevertheless contain organic detritus.

On the Porcupine Abyssal Plain, Gooday (1993) identified that species of Stainforthia (Fursenkoina) are opportunistic, able to exploit high kvels of phytodetritus produced during spring blooms, and occur in low diversity, high dominance assemblages typical of such settings. Thi is also a characteristic of the Celtic Sea assemblages in which S. fusiformis dominates. A feature of such opportunistic foraminifera is their small size and thin-walled tests, adaptations which minimize reproductive energy requirement and permit rapid response to triggering events. Duijnstee and others (1998) demonstrate from a mesocosm experiment that $S$. fusiformis can reproduce at very small sizes when stressed, and Alve (1994) also suggests that their small size may also allow them to be easily transported to pioneer sites. A tolerance of low oxygen concentrations, even anoxia, is offen a feature of bloom-responding foraminifera (Alve, 1990; Sen Gupta and Machain-Castillo, 1993). Bernhard and Alve (1986) demonstrated from nitrogen incubation experiments that $S$. fusiformis can survive anoxia, but that the species suffered some ATP damage, which suggests that it survived by becoming dormant.

L ike other facultative anaerobes, S. fusiformis contains enzymes which allow it to survive without oxygen, but its survival is probably also a function of its maintenance of chloroplasts, which were observed in the Celtic Sea specimens. Chlorophsts are derived from ingested phytoplankton. Leutnegger (1984) proposed that foraminifera which mainta in chlorophsts have evolved thin walls to permit light penetration for photosynthesis, suggesting that this is generally the function of symbionts in foraminifera. However, $S$. fusiformis offen lives well below the depths to which light can penetrate (cf. L eutnegger, 1984) and which is also commonly infaunal. Similarly, Cedhagen (1991) reports chloroplasts in Nonionella labradoricum individuals living deep in the Norwegian Trench; though McFarland and Loew (1983) have shown that waves can focus flashes of high intensity light to great depths, Cedhagen (1991) suggests that the chloroplasts are probably heterotrophic and receive nutrients from their host and in return produce vitamins and lipids. Bernhard and Alve (1996) suggest that the chlorophsts may be a source of food enabling $S$. fusiformis to survive anoxia.

Alve (1994) found monospecific assemblages of $S$. fusiformis in Frierfjord, Norway, in samples from stratified highly organic waters polluted with paper mill waste. Like many of the Celtic Sea specimens, these were coated with a veneer of transparent mud-sized particks. Alve (1994) suggests that these may act as a barrier against harmful 

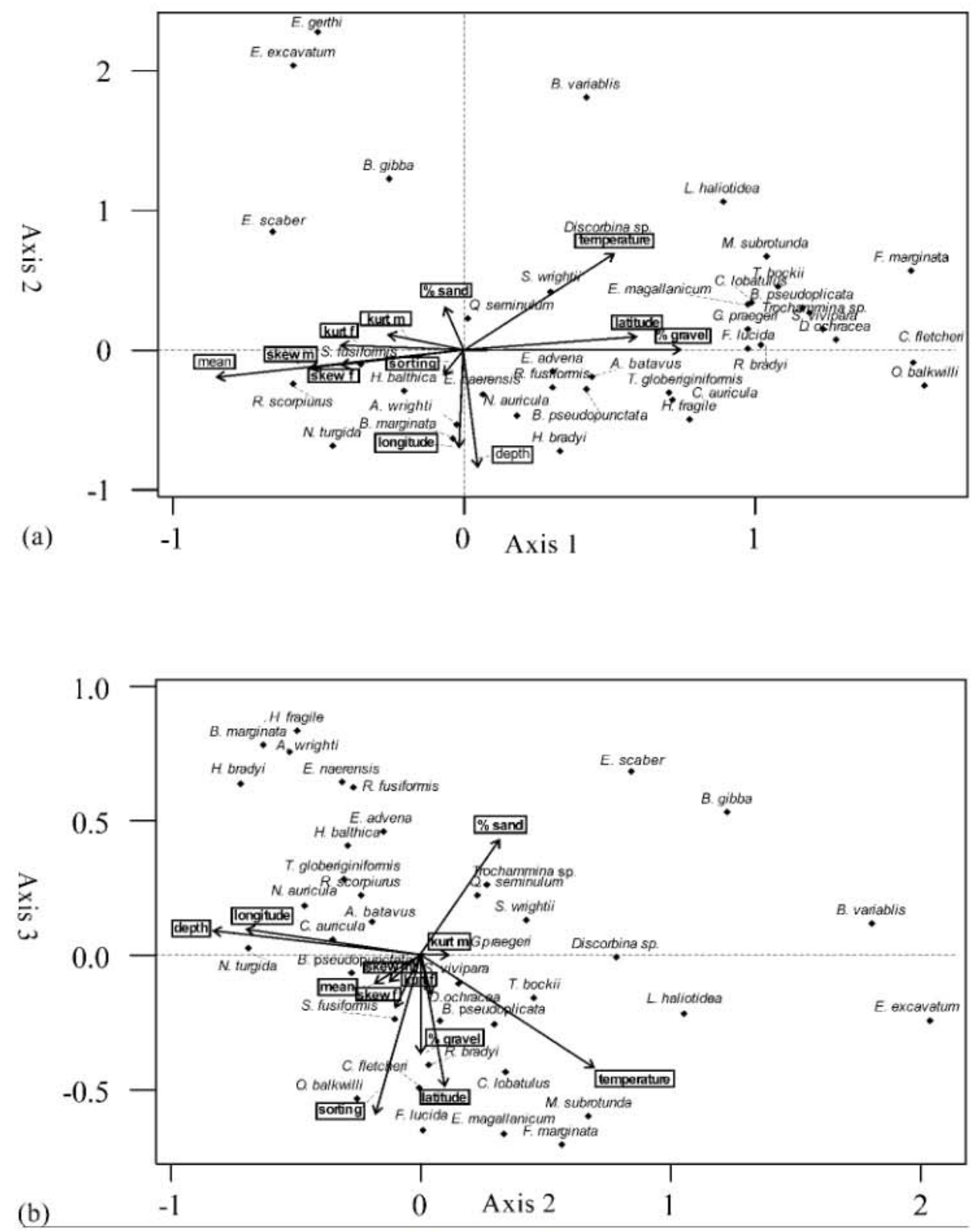

FIGURE 9. Species and environmental variable plot of the CCA on the live data (a) axes 1 and 2, (b) axes 2 and 3.

chemica 1 compounds which are abundant in anoxic habitats, but they could alternatively be normal feeding 'cysts'. The species was ako found living in Drammensfjord (Alve, 1990), having recolonized anoxic sediments, further confirming $S$. fusiformis as an opportunistic element.
An explanation for the distribution of $S$. fusiformis based on the theory of frontal circulation cells is probable since the areas in which this assemblage dominates are also those which rece ive advected phytodetritus from the surface front. The mixed-frontal zone receives organic matter directly

TABLE 4. Summary of the CCA performed on the dead data.

\begin{tabular}{|c|c|c|c|c|c|}
\hline Axes & 1 & 2 & 3 & 4 & Total nertia \\
\hline E igenvalues & 0.26 & 0.18 & 0.16 & 0.04 & 1.54 \\
\hline Species-environment correlations & 0.84 & 0.86 & 0.82 & 0.59 & \\
\hline Cumulative percentage variance of species data & 16.7 & 28.4 & 38.4 & 41.4 & \\
\hline Cumulative percentage variance of species-environment relation & 34.1 & 58 & 78.6 & 84.7 & \\
\hline Sum of all unc onstrained eigenvahes (DCA) & & & & & 1.54 \\
\hline Sum of all canonical eigenvahes (CCA) & & & & & 0.75 \\
\hline
\end{tabular}


TABLE 5. Results of the partial CCA performed on the dead data.

\begin{tabular}{lcc}
\hline \multicolumn{1}{c}{ Environmenta1 variable } & $\begin{array}{c}\text { Sum of } \\
\text { E igenvahes } \\
\text { of partia 1 CCA }\end{array}$ & $\begin{array}{c}\text { \% of the tota1 } \\
\text { explained variance } \\
\text { exclusively } \\
\text { explained by the } \\
\text { environmenta 1 } \\
\text { variable }\end{array}$ \\
\hline depth & 0.03 & 4.77 \\
temperature & 0.02 & 2.65 \\
$\%$ grave1 & 0.01 & 2.39 \\
$\%$ sand & 0.01 & 2.52 \\
mean & 0.02 & 3.32 \\
sorting & 0.01 & 1.86 \\
skew m & 0.03 & 5.04 \\
skew f & 0.02 & 2.92 \\
kurt m & 0.02 & 3.58 \\
kurt f & 0.02 & 3.58 \\
latitude & 0.07 & 10.08 \\
longitude & 0.04 & 5.57 \\
Sum of CCA eigenvalues & 0.75 & \\
Covariance & & 51.72 \\
\hline
\end{tabular}

from the zone of convergence at the surface; the frontalmixed zone also receives matter sourced from the convergence but which has become entrained in flows and delivered to the stratified side of the front. The same circulation theory proposes that the intermediate area is one of divergence, swept free of detritus. This is reflected in the fauna1 data which show a pronounced shadow in this area, not only for the S. fusiformis assemblage, but also in the density of the live foraminifera (Fig. 5a).

S. fusiformis is clearly an opportunistic species whose distribution is linked to the high flux of organic matter and low oxygen concentrations found in the frontal region. Though the preservation potenti 1 of the species is quite low, it is so abundant that it still leaves a sedimentary record. Alve (1994) has previously suggested the use of thi species as a bloom indicator and, in the Celtic Sea, S. fusiformis, above all other species, indicates the position of the seasonal stratification front.

Factor ana lys is a ko defines a distinctive assemblage dominated by $B$. gibba, E. excavatum and E. scaber for the eastern part of the area and the Bristol Channel. The CCA indicates that this distribution is related to \% sand content. $Q$. seminulum, often associated with sandier substrates, is also an important component of this assemblage.

\section{CONCLUSIONS}

Many of the faunal varitions found in this study are clearly linked to the effects of tidal stratification. Four distinct assemblages have been identified by factor analysis of the live data: stratified, mixed, frontal and eastern. Of these, only the fronta 1 assemblage was not identified by factor analysis of the dead data.

1) Frontal assemblage: this assemblage comprises the most abundant live species in the area, S. fusiformis, which is an opportunistic, facultative anaerobe, well-suited to the bloom-like conditions which exist in the frontal region. The majority of the S. fusiformis tests are subject to post-mortem destruction or transport, but nevertheless this species remains a significant part of the dead and, thus, fossil record.

2) Mixed assemblage: this assemblage is characterized by species which prefer coarser sediments such as C. lob- atulus, T. bockii, S. wrightii, A. batavus and $Q$. seminulum. These species are not directly associated with mixed waters but high-energy conditions associated with tidal mixing. Most are epifaunal and this, combined with an association with strong currents, suggests that reworking may be significant. The dead assemblage constitutes robust, easily reworked, larger foraminifera 1 tests which is, in itse If, indicative of the high peak bed stress vectors characteristic of the mixed zone.

3) Stratified assemblage: this assembhge includes $B$. marginata, $H$. balthica, $A$. wrighti, and $N$. turgida. Of these, $B$. marginata and $H$. balthica are over-represented in the dead assemblage, and $A$. wrighti and $N$. turgida underrepresented, and this must have a bearing on their appearance in the fossil record. All species except $N$. turgida are known to tolerate low-oxygen conditions, though this species has been reported from sediments with high organic carbon content (Conradsen, 1993).

4) Eastern assemblage: this assemblage is dominated by $B$. gibba, E. excavatum and E. scaber, species which show an affinity for sandy substrates. However, they all show wide tolerance of a range of other environmenta 1 stresses, suggesting an opportunistic group able to colonize low competition niches.

These data confirm the inferences of Austin and Scourse (1997), and therefore gives independent support to the ir interpretation that the stable isotopic data also reflect this transition.

The study a so identifies some interesting foraminiferal evidence for the mechanisms which deliver nutrients to frontal regions. The predicted cross-frontal transfer of nutrients is supported by the occurrence of stratified-type foraminifera in both the living and dead assemblages underlying the region of the pervasive eddy. The existence of surface converging circulation cells is also apparently recorded. The bwermost cell (Fig. 1) causes a divergence separating areas on the bed to which detritus is delivered, either by direct rain on the mixed side of this zone, or by entrainment into the circulation cells and the delivery to the stratified side. The scenario is captured by the distribution of the foraminiferal populations which are very abundant in the two receptive areas and sparse in between.

The $N$. turgida and $S$. fusiformis distributions highlight the significance of rarer thin walled elements in the fossil record whose poor preservation potent 1 is probably a product of in situ post-mortem destruction rather than transfer out of the basin of deposition.

Statistical analyses indicate that some unmeasured environmenta 1 variables are important in controlling the foraminiferal distributions. The relations between these distributions and the hydrographic data indicate, however, that these variables are linked to seasona1stratification. We specuhte that these variables probably include food supply and bottom water and pore water oxygen concentrations (cf Gooday, 1993), which likely vary from mixed to stratified waters. These remain hypotheses for future fie $\mathbf{l}$ testing.

\section{ACKNOWLEDGMENTS}

The authors thank the captain and crew of the RV Prince Madog for assistance both during and after the research 

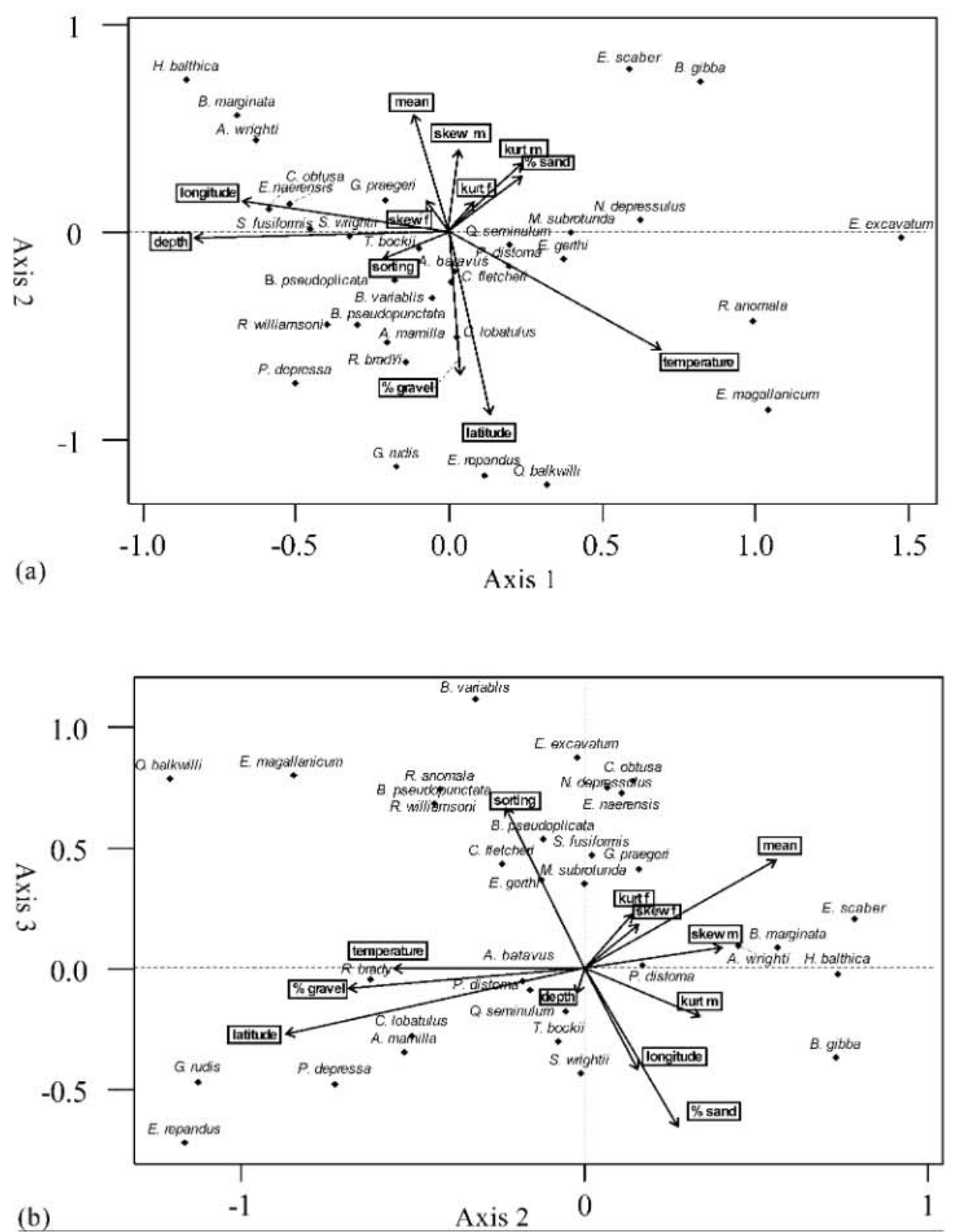

FIGURE 10. Species and environmental variable plot of the CCA on the dead data (a) axes 1 and 2 , (b) axes 2 and 3.

cruises; Anne Hammerstein, Ian Pritchard, Emily Roberts, Iain McMyn, John McDonagh and Grant Fulton for the ir help at sea; Kevin Horsburgh for discussion of the dynamical aspects of stratification; Steve Juggins for help with the multivariate statistica 1 work; and John Whittaker for taxonomic advice on the genus Adercotryma. John Murray provided useful critica 1 comments on a draft of the manuscript. Karen Luise Knudsen is thanked for her advice on point counting statistics in foraminiferal analysis, and GAS wishes to thank her for her expertise in foraminiferal taxonomy. The careful and detailed comments of two anonymous referees were very helpful

\section{REFERENCES}

ALTENBACH, A.V., and SARNTHEIN, M., 1989, Productivity record in benthic foraminifera, in W.H. Berger, V.S. Smetacek and G. Wefer (eds.), Productivity of the Ocean Present and Past: Wiley, Chichester, p. 255-269.

AlVE, E., 1990, Variations in estuarine foraminiferal biofacies with diminishing oxygen concentration in Drammensfjord, SE Norway, in C. Hemleben, M.A. Kaminski, W. Kuhnt and D.B. Scott, (eds.) Palaeoecology, Biostratigraphy, Palaeoceanography and Taxonomy of Agghtinated Foraminifera: Kluwer Academic Publishers, Dordrecht, p. 661-694.

1994. Opportunistic features of the foraminifer Stainforthid fus iform is (Williamson): evidence from Frierfjord, Norway: Journa1 of Micropalaeontology, v. 13, p. 24.

- and MURRAY, J.W., 1997, High benthic fertility and taphonomy of forminifera: a case study of the Skagerrak, North Sea: Marine Micropalae ontology, v. 31, p. 157-175

- and NAGY, J., 1986, Estuarine foraminiferal distribution in Sandebukta, a branch of the Os lo Fjord: Joumal of Foraminiferal Research, v. 16 , p. $157-175$.

AUstiN, R.M., 1991, Modelling Holocene tides on the NW European continental shelf: Terra Nova, v. 3, p. 276-288. 
AUSTIN, WE N and SCOURSE, J.D., 1997, Evohtion of seasona1 stratification in the Celic Sea during the Holocene: Journal of the Geological Society of London, v. 154, p. 249-256.

- and SEJUP, H.P. 1994, Recent shallow water benthic foraminifera from western Norway: ecology and palaeoecologicalsig nific ance: Cushman Foundation Specia1Pub lication, v. 32, p. $103-$ 125 .

BANDY, O.L., INGLE, J.C., and RESIG, J.M., 1965, Foraminiferal trends in the Hyperion outfall area, California: Limnology and Oceanography, v. 10, p. 314-322

BERGER, W.H., Fisher, K., LAI, C., and WU, G., 1989, Ocean productivity and palaeoproductivity: an overview, in W.H. Berger V.S. Smetacek and G. Wefer (eds.), Productivity of the Ocean Present and Past: Wiley, Chichester, p. 1-67.

BerNHARD, J.M., and Alve, E., 1996, Survival ATP pool and ultrastructural characterisation of benthic foraminifera from Drammensfjord (Norway): response to anoxia: Marine Micropalaeonto $l$ gy, v. 28, p. $5-17$.

Bol TOVSKY, E., 1991, On the destruction of foraminiferal tests (laboratory experiments): Revue de Micropaléontology, v. 34, p. $19-$ 25 .

and TOTAH, V.I., 1992, Preservation index and preservation potential of some foraminiferal species: Journal of Foraminiferal Research, v. 22 , p. $267-273$.

BORCARD, D., LEGENDRE, P., and DRAPEAU, P., 1992, Partialling out the spatial component of ecological variation: Ecology, v. 73, p 1045-1055

BRÖNIMANN, P, and WHITTAKER, JE, 1987, A revision of the foraminiferal genus Adercotryma L oeblich and Tappan, with a description of $A$. wrighti sp. nov. from British waters: Bulletin of the British Museum of Natural History (Zoology), v. 52, p. 1928 .

BUZAS, M.A., 1993, Colonization rate of foraminifera in the Indian river, Florida: Journal of Foraminiferal Research, v. 23, p. 156161

CARALP, M., 1989, Abundance of Bulimina exilis and Melonis barleeanum: relationships with marine organic matter: Geo-Marine Letters, v. 9, p. 156-161

CATO, I., 1977, Recent sedimentological and geochemical conditions and pothution problems in two marine areas in southwest Sweden: Striae, v. 6, p. $1-158$

CEDHAGEN, T., 1991, Retention of chloroplasts and bathymetric distribution in the sublittoral foraminiferan Nonionella labradorica: Ophelia, v. 33 , p. 18-30.

CHRISTIANSEN, B., 1958, The foraminifer fauna in the Drobek sound in the Oslo Fjord (Norway): Nytt Magazine der Zoologie, v. 6, p. 5-91

COLL ISON, P., 1980, Vertical distribution of foraminifera off the coast of Northumberland, England: Journal of Foraminiferal Research v. 10, p. $75-78$

CONRADSEN, K., 1993, Recent benthic foraminifera in the southern Kattegat, Scandinavia: distributional pattem and controlling parameters: Boreas, v. 22 , p. $367-382$.

- Bergsten, H., KNUdSen, K.L., NordberG, K., and SeIDENKRANTZ, M.S., 1994, Recent benthic foraminiferaldistribution in the Kattegat and Skagerrak, Scandinavia: Cushman Foundation Specia1 Pub lication, no. 32 , p. $53-68$

DUINSTEE, I.A.P., ERNST, S.R., JANNICK, N.T, and VAN DER ZWANN, G.J., 1998, Population dynamics of benthic foraminifera from the northem A driatic: Proceedings of the 6 th Internationa1 Conference on Palaeoceanography, $\mathrm{L}$ isbon, p. 99

ELL IOTT, A.J., CL ARKE, T., and LI, Z., 1991, Monthly distributions of surface and bottom water temperatures in the northwest European shelf seas: Continenta1 Shelf Research, v. 11, p. 453-466.

FOLK, R.L., 1966, A review of grain size parameters: Sedimentology, v. 6, p. $73-93$.

- and WARD, W.C., 1957, Brazos River Bar, a study in the significance of grainsize parameters: Journal of Sedimentary $\mathrm{Pe}$ trology, v. 27, p. $3-27$

GAlehOUSE, J.S., 1971, Point counting, in R.E. Carver (ed.), Procedures in Sedimentary Petrology: Wiley, New York, p. 385-407.

GOODAY, A.J., 1993, Deep-sea benthic foraminiferal species which exploit phytodetritus: characteristic features and controls on distribution: Marine Micropalaeontology, v. 22, p. 187-205
HALD, M., and STEINSUND, PI., 1992, Distribution of surface sediment benthic foraminifera in the southwestern Barents Sea: Journal of Foraminifera1Research, v. 22, p. 347-362.

HAYNES, J.R., 1973, Cardigan Bay Recent foraminifera: Bulletin of the British Museum (Natura1 History) Zoology Supplement, v. 4, p. $1-245$.

HII L, A.E., JAMES, I.D., LINDEN, P.F., MA TTHEWS, J.P., PRANDLE, D., Simpson, J.H., Gmitrowicz, E.M., SMeED, D.A., L wiZA, K.M.M., Durazo, R., Fox, A.D., and Bowers, D.G., 1993, Dynamics of tidal mixing fronts in the North Sea: Philosophical Transactions of the Royal Society of L ondon, v. A343, p. 431446.

HII L, M.O., and GAUCH, H.G., 1980, Detrended correspondance ana1ysis, an improved ordination technique: Vegetatio, v. 42, p. $47-$ 58

Holligan, P.M., 1981, Biological implications of fronts on the north west European continenta1 shelf Philosophical Transactions of the Royal Society of L ondon, v. A302, p. 547-562.

IMB RIE, J., and KIPP, N.G., 1971, A new micropalaeontologicalmethod for quantitative paleoclimatology: A pplication to a late $\mathrm{Ple}$ is tocene core, in K.K. Turekian (ed.), The L ate Cenozoic Glacial Ages: Yale University Press, Yale, p. 71-181

JAME S, I.D., 1978, A note on the circulation induced by a shallow sea front: Estuarine and CoastalMarine Science, v. 7, p. 197-202

JONES, S.E., 1990. Geophysical properties of surficial sediments: textural and biological contrasts: Unpublished $\mathrm{Ph} . \mathrm{D}$. thes is, University of Wales, Bangor

, JAGO, C.F., BAle, A.J., ChapMan, D., Howl AND, R., and JACKSON, J., 1998, A ggregation and resuspension of suspended particulate matter at a seasonally stratified site in the southern North Sea: physical and biological controls: Continenta1 Shelf $\mathrm{Re}$ search, v. 18, p. 1283-1310.

KIITGAARD-KRISTENSEN, D., and SE JRUP, H.P., 1996, Modern benthic foraminiferal biofacies across the Northern North Sea: Sarsia, v 81 , p. $97-106$

LESLIE, R.J., 1965, Ecology and palaeoecology of Hudson Bay foraminifera: Report of the Bedford Institute of Oceanography, v. 65 , p. $1-192$.

LEUTNE GGER, S., 1984, Symbiosis in benthic foraminifera: specificity and host adaptations: Journal of Foraminiferal Research, v. 14, p. $16-35$.

LOUBERE, P., GARry, A., and LAGoE, M., 1993, Generation of the benthic foraminiferal assemblage: theory and preliminary data: Marine Micropalaeontology, v. 20, p. 165-181.

LUTZE, G.F., 1965, Zur foraminiferen-fauna der Ostsee: Meyniana, v 15 , p. $75-142$.

MACKenSEN, A., SeJRUP, H.P., and JANSEN, E., 1985, The distribution of living foraminifera on the continental slope and rise off southwest Norway: Marine Micropalaeontology, v. 9, p. 275-306.

MCFARLAND, W.N., and LOEW, E.R., 1983, Wave produced changes in underwater light and relation to vision: Environment, Biology and $\mathrm{F}$ isheries, v. 8, p. 173-184.

MELDGAARD, S., and KNUDSEN, K.L., 1991, Metoder til indsampling og oparbejning af prover til foraminifer-analyser: Dansk Natur Dansk Skole, Genoptrykt på Fysisk Institut, p. 48-57.

MURRAY, J.W., 1971, An atlas of British recent foraminiferids: Hei nemann London

- 1979, Recent benthic foraminiferids of the Celtic Sea: Joumal of Foraminifera1 Research, v. 9, p. 193-209

- 1983, Population dynamics of benthic foraminifera: results from the Exe estuary, England: Journal of Foraminifera1Research v. 13, p. $1-12$

, 1986, Living and dead Holocene foraminifera of Lyme Bay, southern England: Journal of Foraminiferal Research, v. 16, p $347-352$.

[, 1991, Ecology and paheoecology of benthic foraminifera Longmans. London, p. 153-154, 313

, 2000, Revised taxonomy, Atlas of British Recent Foraminiferids: Journal of Micropalaeontology, v. 19, 44

NEES, S., 1998, Ground truth in palaeoceanography-good news from the sea floor: Proceedings of the 6th International Conference on Palaeoceanography. Lisbon, p. 5.

PUGH, D.T. and THOMPSON, K.R., 1986, The subtidal behaviour of the 
Celtic sea-I. Sea leve1 and bottom pressures: Continenta1 Shelf Research, v. 5, p. 293-319.

QVALE, G., and VAN WEERING, C.E., 1985, Relationship of surface sediments and benthic foraminiferal distribution patterns in the Norwegian Channe1 (northern North Sea): Marine Micropalaeonto logy, v. 9, p. 469-488.

RISDAL, D., 1963, Foraminiferfaunaen $i$ en de1 sedimentkjemer fra indre Os lofjord: Norges Geologiske Undersøkelser, v. 224, p. 199.

SAVIDGE, G., and Foster, P., 1978, Phytoplankton biology of a front in the Celtic Sea: Nature, v. 271, p. 155-156.

SChAFER, C.T., and COLE, F.E., 1982, Distribution of benthonic foraminifera: their use in delimiting local nearshore environments: Offshore Geology of Eastern Canada, Geological Survey of Canada, paper $74-30$, v. 1 , p. $103-108$

Sen Gupta, B.K., and Machain-CAstillo, L., 1993, Benthic foraminifera in oxygen-poor habitats: Marine Micropalaeontology, $v$. 20 , p. $183-201$.

SIMPSON, J.H., and Bower., D., 1979, Shelf sea fronts' adjustments revealed by satellite IR imagery: Nature, v. 280, p. $648-651$.

STEIN, R., 1985, Rapid grain size analys is of clay and silt fraction by sedigraph 5000D: comparis on with Coulter counter and Atterberg methods: Journal of Sedimentary Petrology, v. 55, p. 590-593.

DE STIGTER, H.C., JORISSEN, J.J., and VAN DER ZWANN, G.J., 1998 , Bathymetric distribution and microhabitat partioning (rose Bengal stained) benthic foraminifera along a shelf to bathyal transect in the southem Adriatic Sea: Journal of Foraminiferal Research, v. 28 , p. $40-65$.

STURR OCK, S., and MURRAY, J.W., 1981, Comparison of low energy and high energy marine middle shelf foraminiferal faunas, Celtic Sea and Western English Channe1 in J. Neale, and M. Brasier (eds.), Micropalaeontology of Shelf Seas: Ellis Horwood, Chichester, p. 250-260.

SVERDRUP, H.U., 1953, On conditions for the vernal blooming of phytoplankton: Journal du Conseil International pour l'Exploration de la Mer, v. 18 , p. $287-295$.

TER BRAAK, C.J.F., 1991, CANOCO. Agricultura1 Mathematics Group, AC Wageningen.

TetT, P.B., JoInt, I.R., PURde, D.A., BaARS, M., OOSterhuis, S.,
Daneri, G., Hannah, F., Mills, D.K., Plummer, D., Pomroy, A.J., WAlNE, A.W., and WitTe, H.J., 1993, Biological consequences of tidal stirring gradients in the North Sea. Philosophical Transactions of the Royal Society of L ondon, v. A343, p. 493508.

Thiede, J., Qvale, G., Skarboe, O., and Strand, J.E., 1981, Benthonic foraminiferal distributions in a southern Norwegian fjord system: a re-evaluation of Oslo Fjord data: Special Publication of the Intermational Association of Sedimentologists, v. 5, p. 469495.

VAN HAREN, J.J.M. and JOORDANS, J.C.A., 1990, Observations of physical and biological parameters at the transition between the southern and centra1 North Sea: Netherlands Journal of Sea Research v. 25 , p. $351-364$.

Verardo, D.J., Froeblich, P.N., and McIntyre, A., 1990, Determination of organic carbon and nitrogen in marine sediments using the Carlo Erba NA-1500 Analyser: Deep-Sea Research, v. 37 , p. $157-165$

VII KS, G., and DEONARINE, B., 1987, Labrador shelf benthic foraminifera and stable oxygen isotopes of Cibicides lobatulus related to the Labrador Current: Canadian Journal of Earth Science, $\mathrm{v}$ 25 , p. $1240-1255$

WALDEN, J., and SMITH, J.P., 1995, Factor analys is: a practical application, in D. Maddy and J.S. Brew (eds.), Statisticalmodelling of Quaternary data: Quaternary Research Association, Cambridge, Technical Guide, v. 5, p. 39-104.

WAL SH, J.J., 1988, On the nature of continental shelves: Academic Press, San Diego, p. 9.

, ROWE, G.T., IVERSON, R.L., and MCROY, C.P., 1981, Biological export of shelf carbon is a sink of the global $\mathrm{CO}_{2}$ cycle: Nature, v. 291, p. 196-201.

WOLLAST, R., 1991, The coastal organic carbon cycle: fluxes, sources and sinks, in R.F.C. Mantoura, J.M. Martin, and R. Wollast (eds.), Ocean Margin Processes in Global Change: Wiley, Chichester, p. $365-381$.

Received 2 June 2000 Accepted 17 December 2000 
APPENDIX I. Live foraminiferal percentage data for those species used in the statistical analyses and the density of foraminifera in each sample.

\begin{tabular}{|c|c|c|c|c|c|c|c|c|c|}
\hline Live \% & T1S01 & $\mathrm{T} 1 \mathrm{~S} 02$ & $\mathrm{~T} 1 \mathrm{~S} 03$ & $\mathrm{~T} 1 \mathrm{~S} 06$ & $\mathrm{~T} 1 \mathrm{~S} 07$ & $\mathrm{~T} 1 \mathrm{~S} 09$ & T1S14 & T1S17 & T1S19 \\
\hline Ammonia batavus & 2 & 2 & 0 & 3 & 0 & 0 & 0 & 0 & 3 \\
\hline Adercotryma wrighti & 0 & 0 & 2 & 0 & 5 & 0 & 0 & 15 & 18 \\
\hline Bulimina gibba & 0 & 2 & 7 & 34 & 8 & 5 & 0 & 0 & 0 \\
\hline Bulimina marginata & 0 & 1 & 0 & 0 & 0 & 1 & 2 & 0 & 7 \\
\hline Bolivina pseudoplicata & 2 & 1 & 3 & 0 & 2 & 0 & 0 & 0 & 0 \\
\hline Bolivinellina pseudopunctata & 1 & 2 & 2 & 0 & 0 & 0 & 0 & 0 & 0 \\
\hline Brizalina variabilis & 0 & 0 & 0 & 0 & 0 & 0 & 0 & 0 & 0 \\
\hline Bolivina/Brizalina group & 4 & 3 & 6 & 0 & 2 & 0 & 1 & 1 & 2 \\
\hline Cibicides fletcheri & 2 & 0 & 1 & 0 & 0 & 0 & 0 & 0 & 0 \\
\hline Cibicides lobatus & 12 & 10 & 4 & 18 & 0 & 0 & 0 & 0 & 0 \\
\hline Cancris auricula & 5 & 6 & 4 & 0 & 17 & 1 & 0 & 5 & 6 \\
\hline Discorb inella sp. & 0 & 0 & 0 & 0 & 0 & 0 & 0 & 0 & 0 \\
\hline Eggerella advena & 0 & 0 & 0 & 0 & 2 & 0 & 0 & 0 & 2 \\
\hline Elphidium excavatum forma selseyensis & 0 & 0 & 6 & 2 & 0 & 0 & 0 & 0 & 0 \\
\hline Elphidium gerthi & 3 & 1 & 0 & 0 & 0 & 0 & 0 & 0 & 0 \\
\hline Elphidium magellanicum & 0 & 0 & 0 & 0 & 0 & 0 & 0 & 0 & 0 \\
\hline Elphidium $\mathrm{cf}$ E. magellanicum & 13 & 4 & 0 & 0 & 0 & 0 & 0 & 0 & 0 \\
\hline Eggerelloides scaber & 0 & 0 & 0 & 0 & 22 & 0 & 0 & 1 & 0 \\
\hline Ep istominella vitrea & 0 & 1 & 2 & 0 & 2 & 0 & 4 & 1 & 3 \\
\hline Fissurina lucida & 0 & 2 & 0 & 0 & 0 & 0 & 0 & 0 & 0 \\
\hline Fissurina marginata & 5 & 0 & 0 & 1 & 0 & 0 & 0 & 0 & 0 \\
\hline Gavelinopsis praegeri & 6 & 3 & 2 & 1 & 2 & 0 & 0 & 0 & 8 \\
\hline Hyalina balthica & 0 & 0 & 0 & 0 & 0 & 0 & 6 & 1 & 2 \\
\hline Haplophragmoides bradyi & 0 & 0 & 0 & 0 & 0 & 0 & 0 & 4 & 0 \\
\hline Haplophragmoides fragile & 0 & 0 & 0 & 0 & 0 & 0 & 0 & 0 & 0 \\
\hline Lamarckina halio tidea & 0 & 0 & 0 & 0 & 0 & 0 & 0 & 0 & 0 \\
\hline Milio linella subrotunda & 4 & 2 & 0 & 2 & 0 & 0 & 0 & 0 & 0 \\
\hline Nonionella auricula & 0 & 6 & 0 & 0 & 0 & 0 & 0 & 1 & 0 \\
\hline Nonionella turgida & 0 & 2 & 0 & 0 & 2 & 1 & 3 & 27 & 5 \\
\hline Ophthalmidium balkwilli & 0 & 3 & 0 & 0 & 0 & 0 & 0 & 0 & 0 \\
\hline Quinqueloculina seminulum & 5 & 3 & 5 & 6 & 6 & 0 & 0 & 0 & 0 \\
\hline Rosalina bradyii & 2 & 1 & 0 & 2 & 0 & 0 & 0 & 0 & 0 \\
\hline Reophax fusiformis & 0 & 0 & 0 & 0 & 2 & 2 & 0 & 0 & 0 \\
\hline Reophax scorpiurus & 0 & 0 & 1 & 0 & 8 & 7 & 0 & 2 & 5 \\
\hline Reophax group & 0 & 0 & 2 & 1 & 9 & 10 & 0 & 2 & 5 \\
\hline Sta inforthia fusiform is & 8 & 29 & 32 & 0 & 9 & 11 & 81 & 34 & 15 \\
\hline Spirillina vivịara & 0 & 0 & 0 & 0 & 0 & 0 & 0 & 0 & 0 \\
\hline Spiroplectammina wrightï & 0 & 0 & 5 & 5 & 0 & 0 & 0 & 0 & 2 \\
\hline Textularia bocki & 15 & 4 & 6 & 11 & 0 & 0 & 0 & 0 & 6 \\
\hline Textilina group & 30 & 4 & 11 & 16 & 0 & 0 & 0 & 0 & 8 \\
\hline Globotrochamminopsis pygmaeus & 1 & 1 & 3 & 0 & 3 & 0 & 0 & 3 & 7 \\
\hline Trochammina sp. & 2 & 2 & 0 & 0 & 0 & 0 & 0 & 0 & 2 \\
\hline Deuterammina (Lepidodeuterammina) ochracea & 1 & 1 & 2 & 0 & 0 & 0 & 0 & 0 & 1 \\
\hline Density per $10 \mathrm{~cm}^{3}$ & 62.06 & 96.41 & 18.71 & 144.44 & 8.84 & 29.53 & 56.87 & 62.03 & 16.25 \\
\hline Count total (n) & 331 & 376 & 263 & 299 & 129 & 378 & 327 & 290 & 260 \\
\hline
\end{tabular}


BENTHIC FORAMINIFERA AND SEASONAL STRA TIFICA TION

APPENDIX I. Extended.

\begin{tabular}{|c|c|c|c|c|c|c|c|c|c|c|c|c|c|c|c|}
\hline $\mathrm{T} 2 \mathrm{~S} 01$ & $\mathrm{~T} 2 \mathrm{~S} 03$ & $\mathrm{~T} 2 \mathrm{~S} 07$ & T2S11 & T2S14 & T2S 16 & T2S19 & $\mathrm{T} 2 \mathrm{~S} 20$ & $\mathrm{~T} 2 \mathrm{~S} 21$ & $\mathrm{~T} 2 \mathrm{~S} 22$ & $\mathrm{~T} 2 \mathrm{~S} 23$ & $\mathrm{~T} 3 \mathrm{~S} 01$ & T3S05 & $\mathrm{T} 3 \mathrm{~S} 03$ & T3S07 & T3\$10 \\
\hline 1 & 3 & 0 & 0 & 0 & 4 & 1 & 3 & 3 & 3 & 0 & 2 & 3 & 0 & 1 & 0 \\
\hline 3 & 26 & 1 & 6 & 2 & 11 & 0 & 2 & 0 & 0 & 0 & 0 & 0 & 1 & 4 & 1 \\
\hline 2 & 0 & 0 & 0 & 0 & 2 & 2 & 0 & 1 & 0 & 0 & 0 & 0 & 3 & 1 & 0 \\
\hline 6 & 8 & 7 & 0 & 5 & 2 & 0 & 0 & 0 & 0 & 0 & 0 & 1 & 0 & 6 & 1 \\
\hline 0 & 0 & 0 & 0 & 0 & 0 & 0 & 2 & 1 & 0 & 1 & 3 & 0 & 1 & 0 & 0 \\
\hline 0 & 3 & 1 & 2 & 0 & 0 & 0 & 2 & 6 & 0 & 0 & 0 & 3 & 1 & 1 & 0 \\
\hline 0 & 0 & 0 & 0 & 0 & 0 & 0 & 0 & 0 & 0 & 0 & 0 & 0 & 0 & 0 & 0 \\
\hline 0 & 3 & 1 & 2 & 0 & 1 & 0 & 3 & 8 & 2 & 2 & 3 & 4 & 1 & 2 & 0 \\
\hline 0 & 0 & 0 & 0 & 0 & 0 & 0 & 2 & 2 & 2 & 0 & 5 & 3 & 0 & 0 & 0 \\
\hline 1 & 0 & 0 & 0 & 2 & 4 & 3 & 4 & 3 & 5 & 16 & 9 & 6 & 2 & 0 & 1 \\
\hline 4 & 6 & 4 & 3 & 2 & 5 & 41 & 10 & 26 & 19 & 0 & 20 & 34 & 35 & 1 & 1 \\
\hline 0 & 0 & 0 & 0 & 0 & 0 & 0 & 0 & 0 & 0 & 0 & 0 & 0 & 0 & 0 & 0 \\
\hline 4 & 0 & 0 & 0 & 2 & 5 & 0 & 0 & 0 & 0 & 0 & 0 & 0 & 1 & 0 & 1 \\
\hline 0 & 0 & 0 & 0 & 0 & 0 & 0 & 0 & 0 & 1 & 0 & 0 & 1 & 0 & 0 & 0 \\
\hline 0 & 0 & 0 & 0 & 0 & 0 & 0 & 0 & 0 & 0 & 0 & 0 & 0 & 0 & 0 & 0 \\
\hline 0 & 0 & 0 & 0 & 0 & 4 & 0 & 2 & 1 & 0 & 0 & 2 & 0 & 0 & 0 & 0 \\
\hline 0 & 0 & 0 & 0 & 0 & 0 & 0 & 0 & 0 & 0 & 0 & 1 & 0 & 0 & 0 & 0 \\
\hline 0 & 5 & 0 & 2 & 0 & 0 & 0 & 0 & 0 & 0 & 0 & 0 & 0 & 0 & 1 & 1 \\
\hline 21 & 2 & 0 & 0 & 2 & 5 & 0 & 0 & 1 & 1 & 0 & 0 & 0 & 1 & 5 & 1 \\
\hline 0 & 0 & 0 & 0 & 0 & 0 & 0 & 0 & 0 & 0 & 0 & 0 & 0 & 0 & 0 & 0 \\
\hline 0 & 0 & 0 & 0 & 0 & 0 & 0 & 0 & 0 & 0 & 1 & 3 & 0 & 0 & 0 & 0 \\
\hline 13 & 0 & 0 & 0 & 2 & 7 & 2 & 11 & 2 & 14 & 15 & 7 & 3 & 4 & 0 & 0 \\
\hline 2 & 3 & 2 & 0 & 0 & 0 & 0 & 0 & 0 & 0 & 0 & 0 & 0 & 0 & 2 & 0 \\
\hline 0 & 0 & 0 & 0 & 5 & 0 & 0 & 0 & 0 & 0 & 0 & 0 & 1 & 0 & 5 & 0 \\
\hline 6 & 16 & 0 & 0 & 5 & 4 & 0 & 5 & 0 & 2 & 3 & 1 & 1 & 1 & 0 & 0 \\
\hline 0 & 0 & 0 & 0 & 0 & 0 & 0 & 0 & 1 & 0 & 0 & 0 & 0 & 1 & 0 & 0 \\
\hline 0 & 0 & 0 & 0 & 0 & 0 & 0 & 0 & 0 & 1 & 2 & 0 & 0 & 0 & 0 & 0 \\
\hline 0 & 0 & 0 & 0 & 0 & 2 & 0 & 0 & 0 & 0 & 1 & 0 & 0 & 0 & 1 & 0 \\
\hline 5 & 8 & 24 & 19 & 2 & 4 & 1 & 0 & 0 & 2 & 0 & 0 & 1 & 12 & 7 & 1 \\
\hline 0 & 0 & 0 & 0 & 0 & 1 & 0 & 5 & 1 & 0 & 2 & 3 & 0 & 2 & 0 & 0 \\
\hline 10 & 3 & 0 & 0 & 9 & 9 & 0 & 3 & 2 & 1 & 2 & 2 & 1 & 1 & 2 & 1 \\
\hline 0 & 0 & 4 & 0 & 0 & 0 & 1 & 2 & 4 & 0 & 0 & 4 & 3 & 2 & 0 & 0 \\
\hline 1 & 1 & 0 & 2 & 23 & 2 & 1 & 0 & 0 & 0 & 0 & 0 & 2 & 2 & 0 & 0 \\
\hline 0 & 2 & 0 & 3 & 0 & 4 & 0 & 0 & 0 & 0 & 0 & 0 & 2 & 1 & 1 & 1 \\
\hline 1 & 3 & 0 & 5 & 23 & 7 & 1 & 0 & 0 & 0 & 0 & 0 & 4 & 3 & 1 & 1 \\
\hline 3 & 4 & 53 & 56 & 14 & 5 & 37 & 2 & 6 & 17 & 0 & 1 & 8 & 16 & 60 & 90 \\
\hline 2 & 0 & 0 & 0 & 0 & 0 & 0 & 5 & 4 & 2 & 4 & 1 & 3 & 1 & 0 & 0 \\
\hline 1 & 0 & 0 & 0 & 0 & 0 & 0 & 0 & 0 & 0 & 0 & 0 & 1 & 0 & 0 & 0 \\
\hline 8 & 0 & 0 & 0 & 2 & 5 & 1 & 7 & 5 & 3 & 23 & 12 & 0 & 4 & 0 & 0 \\
\hline 9 & 0 & 0 & 0 & 2 & 5 & 1 & 7 & 6 & 3 & 23 & 12 & 1 & 4 & 0 & 0 \\
\hline 0 & 0 & 0 & 3 & 9 & 4 & 0 & 8 & 2 & 1 & 4 & 4 & 6 & 1 & 0 & 0 \\
\hline 0 & 0 & 0 & 0 & 9 & 1 & 0 & 0 & 0 & 1 & 1 & 3 & 0 & 0 & 0 & 0 \\
\hline 1 & 0 & 0 & 0 & 0 & 2 & 1 & 6 & 5 & 4 & 5 & 0 & 5 & 2 & 0 & 0 \\
\hline 41.87 & 45.78 & 63.18 & 40.00 & 4.00 & 92.22 & 33.50 & 75.42 & 11.18 & 12.15 & 60.66 & 15.47 & 34.14 & 30.51 & 200.32 & 75.07 \\
\hline 314 & 293 & 338 & 320 & 44 & 166 & 273 & 331 & 170 & 215 & 337 & 232 & 239 & 302 & 621 & 379 \\
\hline
\end{tabular}


APPENDIX I. Continued.

\begin{tabular}{|c|c|c|c|c|c|c|c|c|c|c|c|}
\hline Live $\%$ & $\mathrm{~T} 3 \$ 11$ & $\mathrm{~T} 3 \mathrm{~S} 13$ & $\mathrm{~T} 3 \mathrm{~S} 15$ & $\mathrm{~T} 3 \mathrm{~S} 16$ & T3S17 & $\mathrm{T} 3 \mathrm{~S} 19$ & $\mathrm{~T} 3 \mathrm{~S} 23$ & $\mathrm{~T} 6 \mathrm{~S} 02$ & $\mathrm{~T} 6 \mathrm{~S} 06$ & $\mathrm{~T} 6 \mathrm{~S} 08$ & $\mathrm{~T} 6 \mathrm{~S} 10$ \\
\hline A. batavus & 0 & 3 & 4 & 0 & 0 & 4 & 3 & 2 & 0 & 0 & 0 \\
\hline A. wrighti & 0 & 0 & 9 & 4 & 5 & 12 & 11 & 0 & 2 & 0 & 0 \\
\hline B. $g i b b a$ & 3 & 0 & 2 & 0 & 0 & 0 & 0 & 11 & 2 & 2 & 13 \\
\hline B. marginata & 0 & 0 & 7 & 1 & 2 & 8 & 6 & 0 & 0 & 0 & 0 \\
\hline B. pseudoplicata & 0 & 0 & 0 & 0 & 0 & 0 & 0 & 0 & 0 & 0 & 0 \\
\hline B. pseudopunctata & 1 & 1 & 0 & 0 & 0 & 0 & 0 & 0 & 0 & 0 & 0 \\
\hline B. variabilis & 0 & 0 & 0 & 0 & 0 & 0 & 0 & 0 & 2 & 0 & 0 \\
\hline Bolivina group & 1 & 1 & 0 & 0 & 0 & 2 & 2 & 0 & 2 & 1 & 0 \\
\hline C. fletcheri & 0 & 0 & 0 & 0 & 0 & 0 & 0 & 0 & 0 & 0 & 0 \\
\hline C. lobatulus & 0 & 0 & 1 & 0 & 0 & 1 & 0 & 3 & 2 & 2 & 0 \\
\hline C. auricula & 2 & 5 & 6 & 5 & 2 & 5 & 10 & 0 & 0 & 0 & 0 \\
\hline Discorbinella sp. & 0 & 0 & 0 & 0 & 0 & 0 & 0 & 0 & 0 & 4 & 0 \\
\hline E. advena & 1 & 2 & 0 & 0 & 0 & 0 & 4 & 0 & 0 & 2 & 0 \\
\hline E. excavatum forma selseyensis & 0 & 0 & 0 & 0 & 0 & 0 & 0 & 0 & 0 & 0 & 0 \\
\hline E. gerthi & 0 & 0 & 0 & 0 & 0 & 0 & 0 & 0 & 2 & 1 & 0 \\
\hline E. magellanicum & 0 & 0 & 0 & 0 & 0 & 0 & 0 & 8 & 0 & 0 & 0 \\
\hline E. cf E. magellanicum & 0 & 0 & 0 & 0 & 0 & 0 & 0 & 0 & 19 & 0 & 0 \\
\hline E. scaber & 0 & 0 & 4 & 0 & 0 & 1 & 0 & 0 & 0 & 0 & 0 \\
\hline E. vitrea & 0 & 5 & 0 & 0 & 0 & 0 & 2 & 0 & 0 & 3 & 0 \\
\hline F. lucida & 0 & 0 & 0 & 0 & 0 & 0 & 0 & 0 & 0 & 0 & 0 \\
\hline F. marginata & 0 & 0 & 0 & 0 & 0 & 0 & 0 & 0 & 0 & 0 & 0 \\
\hline G. praegeri & 0 & 0 & 4 & 0 & 0 & 0 & 3 & 2 & 15 & 4 & 3 \\
\hline$H$. balthica & 0 & 0 & 0 & 0 & 0 & 1 & 1 & 0 & 0 & 0 & 8 \\
\hline H. bradyi & 0 & 0 & 1 & 0 & 0 & 1 & 2 & 0 & 0 & 0 & 0 \\
\hline H. fragile & 0 & 0 & 0 & 0 & 0 & 0 & 2 & 0 & 0 & 0 & 0 \\
\hline L. haliotidea & 0 & 0 & 0 & 0 & 0 & 0 & 0 & 0 & 8 & 0 & 0 \\
\hline M. subrotunda & 0 & 0 & 0 & 0 & 0 & 0 & 0 & 0 & 0 & 0 & 0 \\
\hline N. auricula & 0 & 0 & 0 & 2 & 5 & 8 & 4 & 0 & 0 & 1 & 0 \\
\hline N. turgida & 4 & 6 & 14 & 8 & 2 & 5 & 13 & 0 & 0 & 0 & 0 \\
\hline O. balkwilli & 0 & 0 & 0 & 0 & 0 & 0 & 0 & 0 & 0 & 0 & 0 \\
\hline$Q$. seminulum & 0 & 0 & 0 & 0 & 0 & 0 & 0 & 0 & 2 & 0 & 0 \\
\hline$\widetilde{R}$ bradyi & 0 & 0 & 0 & 0 & 0 & 0 & 0 & 6 & 0 & 0 & 0 \\
\hline R. fusiformis & 0 & 0 & 2 & 0 & 0 & 2 & 0 & 0 & 0 & 0 & 0 \\
\hline R. scorpiurus & 4 & 0 & 20 & 0 & 2 & 0 & 0 & 0 & 0 & 0 & 0 \\
\hline$R$ group & 4 & 0 & 21 & 2 & 2 & 2 & 0 & 0 & 0 & 0 & 0 \\
\hline S. fusiformis & 78 & 64 & 15 & $7 \overline{1}$ & 73 & 44 & 25 & 63 & 10 & 65 & 67 \\
\hline S. vivipara & 0 & 0 & 0 & 0 & 0 & 0 & 0 & 0 & 2 & 0 & 0 \\
\hline S. wrightii & 0 & 0 & 0 & 0 & 0 & 0 & 0 & 0 & 2 & 0 & 0 \\
\hline T. bockü & 0 & 0 & 0 & 0 & 0 & 0 & 0 & 3 & 19 & 2 & 0 \\
\hline Textilina group & 0 & 0 & 2 & 0 & 0 & 0 & 0 & 3 & 21 & 3 & 0 \\
\hline G. pygmaeus & 0 & 1 & 2 & 0 & 1 & 0 & 0 & 0 & 0 & 0 & 0 \\
\hline Trochammina sp. & 0 & 0 & 0 & 0 & 0 & 0 & 0 & 0 & 0 & 0 & 0 \\
\hline D. ochracea & 0 & 0 & 0 & 0 & 0 & 0 & 0 & 0 & 6 & 1 & 0 \\
\hline Density per $10 \mathrm{~cm}^{3}$ & 29.34 & 11.50 & 31.03 & 81.41 & 76.94 & 67.64 & 57.00 & 8.27 & 3.84 & 30.89 & 33.92 \\
\hline Count tota $1(\mathrm{n})$ & 313 & 176 & 256 & 346 & 327 & 372 & 342 & 62 & 48 & 278 & 424 \\
\hline
\end{tabular}


BENTHIC FORAMINIFERA AND SEASONAL STRA TIFICA TION

APPENDIX I.. Continued, Extended

\begin{tabular}{|c|c|c|c|c|c|c|c|c|c|c|c|c|c|c|c|}
\hline T6S 12 & T6S14 & T6S 16 & $\mathrm{~T} 7 \mathrm{~S} 02$ & T7S 06 & $\mathrm{~T} 7 \mathrm{~S} 10$ & T7S 16 & TSSO1 & $\mathrm{TSS} 02$ & T8S05 & TSSOS & TSSO9 & T8S 10 & T8S 13 & T8S 16 & T\&S 20 \\
\hline 0 & 0 & 2 & 0 & 0 & 0 & 0 & 0 & 0 & 0 & 0 & 0 & 0 & 0 & 0 & 2 \\
\hline 2 & 4 & 0 & 0 & 3 & 3 & 1 & 0 & 0 & 0 & 0 & 0 & 0 & 0 & 0 & 0 \\
\hline 2 & 0 & 0 & 0 & 1 & 0 & 0 & 0 & 0 & 3 & 35 & 17 & 57 & 43 & 19 & 20 \\
\hline 0 & 2 & 0 & 0 & 0 & 0 & 2 & 2 & 0 & 0 & 0 & 0 & 0 & 0 & 0 & 0 \\
\hline 0 & 0 & 0 & 0 & 0 & 0 & 0 & 0 & 0 & 0 & 0 & 0 & 0 & 0 & 0 & 0 \\
\hline 0 & 0 & 1 & 0 & 0 & 0 & 0 & 2 & 0 & 0 & 0 & 0 & 0 & 0 & 0 & 2 \\
\hline 0 & 0 & 0 & 0 & 0 & 0 & 0 & 0 & 0 & 0 & 0 & 0 & 0 & 0 & 0 & 5 \\
\hline 0 & 0 & 1 & 0 & 0 & 0 & 0 & 2 & 0 & 0 & 0 & 0 & 0 & 0 & 0 & 7 \\
\hline 0 & 0 & 0 & 0 & 0 & 0 & 0 & 0 & 0 & 0 & 0 & 0 & 0 & 0 & 0 & 0 \\
\hline 0 & 0 & 0 & 0 & 0 & 0 & 0 & 0 & 0 & 0 & 0 & 0 & 0 & 0 & 0 & 2 \\
\hline 3 & 3 & 2 & 0 & 0 & 5 & 0 & 0 & 3 & 4 & 0 & 7 & 2 & 2 & 0 & 0 \\
\hline 0 & 0 & 0 & 0 & 0 & 0 & 0 & 0 & 0 & 0 & 0 & 0 & 0 & 0 & 0 & 0 \\
\hline 0 & 0 & 0 & 0 & 1 & 0 & 0 & 0 & 0 & 0 & 0 & 0 & 0 & 0 & 0 & 2 \\
\hline 0 & 0 & 0 & 0 & 0 & 0 & 0 & 0 & 0 & 0 & 6 & 0 & 4 & 13 & 48 & 14 \\
\hline 0 & 0 & 0 & 0 & 0 & 0 & 0 & 0 & 0 & 0 & 0 & 2 & 0 & 0 & 1 & 2 \\
\hline 0 & 0 & 0 & 0 & 0 & 0 & 0 & 0 & 0 & 0 & 0 & 0 & 0 & 0 & 0 & 0 \\
\hline 0 & 0 & 0 & 0 & 0 & 0 & 0 & 0 & 0 & 0 & 0 & 0 & 0 & 0 & 0 & 0 \\
\hline 1 & 2 & 0 & 0 & 0 & 3 & 0 & 0 & 1 & 3 & 12 & 7 & 0 & 11 & 7 & 4 \\
\hline 3 & 0 & 2 & 0 & 8 & 1 & 0 & 0 & 0 & 1 & 0 & 0 & 0 & 0 & 0 & 0 \\
\hline 0 & 0 & 0 & 5 & 0 & 0 & 0 & 0 & 0 & 0 & 0 & 2 & 0 & 0 & 0 & 0 \\
\hline 0 & 0 & 0 & 3 & 0 & 0 & 0 & 0 & 0 & 0 & 0 & 0 & 0 & 0 & 0 & 0 \\
\hline 1 & 0 & 0 & 3 & 3 & 0 & 0 & 0 & 0 & 0 & 0 & 0 & 0 & 0 & 0 & 4 \\
\hline 0 & 0 & 0 & 0 & 0 & 0 & 0 & 0 & 0 & 0 & 0 & 0 & 0 & 0 & 0 & 0 \\
\hline 0 & 0 & 0 & 0 & 0 & 0 & 0 & 0 & 0 & 0 & 0 & 0 & 0 & 0 & 0 & 0 \\
\hline 0 & 0 & 0 & 5 & 0 & 0 & 0 & 0 & 0 & 0 & 0 & 0 & 0 & 0 & 0 & 0 \\
\hline 0 & 0 & 0 & 0 & 0 & 0 & 0 & 0 & 0 & 0 & 0 & 0 & 0 & 0 & 0 & 3 \\
\hline 0 & 0 & 0 & 0 & 0 & 0 & 0 & 0 & 0 & 0 & 0 & 0 & 0 & 0 & 0 & 0 \\
\hline 2 & 0 & 0 & 0 & 1 & 0 & 0 & 0 & 0 & 0 & 0 & 0 & 0 & 0 & 0 & 0 \\
\hline 11 & 10 & 9 & 0 & 5 & 8 & 5 & 31 & 11 & 9 & 0 & 0 & 0 & 0 & 0 & 0 \\
\hline 0 & 0 & 0 & 0 & 0 & 0 & 0 & 0 & 0 & 0 & 0 & 0 & 0 & 0 & 0 & 0 \\
\hline 2 & 0 & 0 & 5 & 0 & 0 & 1 & 0 & 0 & 33 & 0 & 5 & 2 & 4 & 0 & 2 \\
\hline 0 & 0 & 0 & 0 & 0 & 0 & 0 & 0 & 0 & 0 & 0 & 0 & 0 & 0 & 0 & 0 \\
\hline 0 & 2 & 0 & 0 & 0 & 0 & 0 & 0 & 0 & 3 & 0 & 0 & 0 & 0 & 0 & 2 \\
\hline 6 & 6 & 6 & 0 & 2 & 7 & 0 & 0 & 1 & 7 & 0 & 0 & 0 & 0 & 0 & 0 \\
\hline 6 & 8 & 6 & 0 & 2 & 8 & 0 & 0 & 1 & 10 & 0 & 0 & 0 & 0 & 0 & 2 \\
\hline 62 & 67 & 70 & 70 & 61 & 67 & 88 & 59 & 79 & 32 & 47 & 57 & 34 & 24 & 23 & 18 \\
\hline 0 & 0 & 0 & 0 & 0 & 0 & 0 & 0 & 0 & 0 & 0 & 0 & 0 & 0 & 0 & 4 \\
\hline 0 & 0 & 0 & 0 & 0 & 0 & 0 & 0 & 0 & 0 & 0 & 0 & 0 & 0 & 0 & 0 \\
\hline 0 & 0 & 0 & 0 & 2 & 0 & 0 & 0 & 0 & 0 & 0 & 0 & 0 & 0 & 0 & 5 \\
\hline 0 & 0 & 0 & 0 & 2 & 0 & 0 & 0 & 0 & 0 & 0 & 0 & 0 & 0 & 0 & 5 \\
\hline 0 & 0 & 0 & 0 & 0 & 0 & 0 & 0 & 0 & 0 & 0 & 0 & 0 & 0 & 0 & 0 \\
\hline 0 & 0 & 0 & 0 & 0 & 0 & 0 & 0 & 0 & 0 & 0 & 0 & 0 & 0 & 0 & 2 \\
\hline 0 & 0 & 0 & 0 & 0 & 0 & 0 & 0 & 0 & 0 & 0 & 0 & 0 & 0 & 0 & 2 \\
\hline 17.67 & 15.09 & 37.22 & 6.73 & 205.50 & 31.65 & 23.47 & 29.33 & 8.97 & 21.47 & 1.33 & 3.82 & 10.42 & 22.70 & 51.15 & 10.00 \\
\hline 212 & 264 & 335 & 37 & 410 & 269 & 264 & 308 & 175 & 153 & 17 & 42 & 125 & 227 & 211 & 130 \\
\hline
\end{tabular}


APPENDIX II. Dead foraminiferal percentage data for those species used in the statistical analyses and the density of foraminifera in each sample.

\begin{tabular}{|c|c|c|c|c|c|c|c|c|c|c|c|}
\hline Dead $\%$ & $\mathrm{~T} 1 \mathrm{~S} 01$ & $\mathrm{~T} 1 \mathrm{~S} 02$ & $\mathrm{~T} 1 \mathrm{~S} 03$ & $\mathrm{~T} 1 \mathrm{~S} 06$ & $\mathrm{~T} 1 \mathrm{~S} 07$ & $\mathrm{~T} 1 \mathrm{~S} 09$ & T1S14 & T1S17 & T1S19 & $\mathrm{T} 2 \mathrm{~S} 01$ & $\mathrm{~T} 2 \mathrm{~S} 03$ \\
\hline Ammonia batavus & 3 & 4 & 4 & 3 & 3 & 3 & 0 & 4 & 7 & 4 & 3 \\
\hline Adercotryma wrighti & 0 & 0 & 0 & 0 & 0 & 0 & 0 & 0 & 0 & 0 & 0 \\
\hline Asterigerinata mamilla & 0 & 0 & 0 & 0 & 0 & 1 & 0 & 0 & 0 & 0 & 0 \\
\hline Bulimina gibba & 8 & 4 & 5 & 34 & 38 & 27 & 2 & 0 & 0 & 0 & 0 \\
\hline Bulimina marginata & 4 & 0 & 0 & 0 & 1 & 0 & 3 & 24 & 17 & 11 & 39 \\
\hline Bolivina pseudoplicata & 3 & 1 & 1 & 0 & 0 & 2 & 8 & 4 & 2 & 0 & 4 \\
\hline Bolivinellina pseudopunctata & 1 & 1 & 1 & 0 & 0 & 0 & 4 & 0 & 0 & 1 & 0 \\
\hline Brizalina variabilis & 2 & 0 & 0 & 0 & 0 & 0 & 0 & 2 & 0 & 0 & 0 \\
\hline Bolivina/Brizalina group & 7 & 3 & 3 & 0 & 0 & 4 & 17 & 8 & 3 & 2 & 6 \\
\hline Cibicides lobatulus & 14 & 19 & 20 & 18 & 18 & 11 & 7 & 3 & 6 & 2 & 2 \\
\hline Cibicides fletcheri & 3 & 0 & 0 & 0 & 2 & 0 & 2 & 0 & & 0 & 2 \\
\hline Cassidulina obtusa & 0 & 0 & 0 & 0 & 0 & 0 & 6 & 4 & 2 & 0 & 4 \\
\hline \multicolumn{12}{|l|}{ Elphidium excavatum forma } \\
\hline selseyensis & 5 & 3 & 7 & 2 & 2 & 5 & 0 & 0 & 0 & 0 & 0 \\
\hline Elphidium gerthi & 2 & 2 & 2 & 0 & 2 & 6 & 3 & 0 & & 0 & 0 \\
\hline Elphidium magellanicum & 7 & 1 & 0 & 0 & 0 & 0 & 0 & 0 & 0 & 0 & 0 \\
\hline Elphidium cf $E$. magellanicum & 2 & 2 & 0 & 0 & 0 & 0 & 0 & 0 & 0 & 0 & 0 \\
\hline Eponides repandus & 0 & 0 & 0 & 0 & 0 & 0 & 0 & 0 & 0 & 0 & 0 \\
\hline Eggerelloides scaber & 0 & 0 & 0 & 0 & 0 & 0 & 1 & 2 & 0 & 2 & 2 \\
\hline Epistominella vitrea & 1 & 0 & 0 & 0 & 0 & 0 & 8 & 6 & 2 & 0 & 1 \\
\hline Gavelinopsis praegeri & 4 & 0 & 1 & 1 & 1 & 6 & 9 & 4 & 2 & 2 & 4 \\
\hline Gaudyrina rudis & 0 & 1 & 1 & 0 & 0 & 0 & 0 & 0 & 0 & 0 & 0 \\
\hline Hyalina balthica & 0 & 0 & 0 & 0 & 0 & 0 & 1 & 10 & 6 & 13 & 9 \\
\hline Miliolinella subrotunda & 0 & 0 & 0 & 2 & 2 & 3 & 0 & 0 & 0 & 0 & 0 \\
\hline Nonion depressulus & 0 & 0 & 0 & 0 & 0 & 0 & 0 & 0 & 0 & 0 & 0 \\
\hline Nonion turgida & 0 & 0 & 0 & 0 & 0 & 0 & 2 & 2 & 0 & 0 & 1 \\
\hline Ophthalmidium balkwilli & 0 & 0 & 0 & 0 & 0 & 0 & 0 & 0 & 0 & 0 & 0 \\
\hline Pyrgo depressa & 0 & 0 & 0 & 1 & 0 & 0 & 0 & 0 & 0 & 0 & 0 \\
\hline Planorbulina distoma & 1 & 2 & 0 & 6 & 2 & 0 & 0 & 0 & 0 & 0 & 0 \\
\hline Quinqueloculina seminulum & 4 & 15 & 16 & 6 & 5 & 5 & 5 & 8 & 6 & 5 & 3 \\
\hline Rosalina bradyi & 1 & 4 & 5 & 2 & 0 & 0 & 2 & 0 & 1 & 0 & 0 \\
\hline Rosalina anomala & 2 & 0 & 0 & 0 & 0 & 0 & 0 & 0 & 0 & 0 & 0 \\
\hline Rosalina williamsoni & 0 & 0 & 0 & 0 & 0 & 1 & 3 & 1 & 0 & 0 & 0 \\
\hline Stainforthia fusiformis & 5 & 8 & 2 & 0 & 0 & 4 & 6 & 6 & 2 & 2 & 3 \\
\hline Spiroplectammina wrightii & 2 & 4 & 6 & 5 & 3 & 2 & 0 & 1 & 19 & 18 & 1 \\
\hline Textularia bockii & 6 & 13 & 20 & 11 & 12 & 8 & 5 & 3 & 15 & 28 & 8 \\
\hline Textilina group & 8 & 17 & 25 & 16 & 15 & 10 & 5 & 4 & 34 & 46 & 9 \\
\hline Density per $10 \mathrm{~cm}^{3}$ & 2760.00 & 1635.16 & 876.86 & 5200.00 & 8112.33 & 11025.00 & 17780.87 & 11242.78 & 3408.75 & 993.00 & 4851.56 \\
\hline
\end{tabular}


BENTHIC FORAMINIFERA AND SEASONAL STRA TIFICA TION

APPENDIX II. Extended

\begin{tabular}{|c|c|c|c|c|c|c|c|c|c|c|c|c|c|c|}
\hline $\mathrm{T} 2 \mathrm{~S} 07$ & T2S 11 & T2S 14 & $\mathrm{~T} 2 \mathrm{~S} 16$ & T2S 19 & $\mathrm{~T} 2 \mathrm{~S} 20$ & $\mathrm{~T} 2 \mathrm{~S} 21$ & $\mathrm{~T} 2 \mathrm{~S} 22$ & $\mathrm{~T} 2 \mathrm{~S} 23$ & $\mathrm{~T} 3 \mathrm{~S} 01$ & $\mathrm{~T} 3 \mathrm{~S}_{03}$ & $\mathrm{~T} 3 \mathrm{~S} 05$ & $\mathrm{~T} 3 \mathrm{~S} 07$ & $\mathrm{~T} 3 \mathrm{~S} 10$ & T3S11 \\
\hline 3 & 5 & 3 & 3 & 8 & 8 & 3 & 3 & 7 & 9 & 7 & 5 & 0 & 2 & 2 \\
\hline 1 & 4 & 0 & 0 & 0 & 0 & 0 & 0 & 0 & 0 & 0 & 0 & 0 & 0 & 0 \\
\hline 0 & 1 & 0 & 1 & 3 & 0 & 0 & 0 & 0 & 0 & 2 & 0 & 0 & 3 & 2 \\
\hline 0 & 4 & 3 & 0 & 1 & 0 & 2 & 0 & 0 & 1 & 0 & 0 & 0 & 4 & 5 \\
\hline 28 & 18 & 0 & 0 & 0 & 0 & 0 & 0 & 0 & 0 & 0 & 0 & 58 & 2 & 0 \\
\hline 3 & 0 & 0 & 0 & 0 & 1 & 4 & 2 & 3 & 3 & 2 & 3 & 3 & 3 & 3 \\
\hline 2 & 0 & 0 & 0 & 0 & 0 & 3 & 2 & 0 & 0 & 0 & 0 & 0 & 1 & 0 \\
\hline 2 & 0 & 0 & 0 & 0 & 0 & 0 & 4 & 0 & 0 & 0 & 0 & 0 & 0 & 0 \\
\hline 8 & 0 & 1 & 1 & 0 & 2 & 8 & 8 & 3 & 5 & 3 & 4 & 5 & 4 & 4 \\
\hline 4 & 12 & 27 & 35 & 32 & 26 & 14 & 14 & 26 & 24 & 27 & 32 & 2 & 28 & 24 \\
\hline 1 & 0 & 0 & 0 & 4 & 2 & 2 & 8 & 0 & 4 & 9 & 3 & 1 & 0 & 2 \\
\hline 6 & 0 & 0 & 0 & 0 & 0 & 0 & 1 & 0 & 0 & 2 & 0 & 2 & 0 & 5 \\
\hline 0 & 2 & 0 & 0 & 0 & 0 & 3 & 1 & 0 & 0 & 0 & 1 & 0 & 0 & 0 \\
\hline 0 & 1 & 0 & 0 & 2 & 0 & 2 & 1 & 2 & 1 & 1 & 0 & 0 & 0 & 2 \\
\hline 0 & 0 & 0 & 0 & 0 & 0 & 3 & 2 & 0 & 1 & 0 & 0 & 0 & 0 & 0 \\
\hline 0 & 0 & 0 & 0 & 2 & 0 & 0 & 3 & 0 & 4 & 2 & 2 & 0 & 0 & 0 \\
\hline 0 & 0 & 0 & 0 & 0 & 1 & 0 & 0 & 5 & 0 & 0 & 0 & 0 & 0 & 0 \\
\hline 1 & 2 & 0 & 0 & 0 & 0 & 0 & 0 & 0 & 0 & 0 & 0 & 0 & 0 & 0 \\
\hline 4 & 0 & 0 & 0 & 0 & 0 & 3 & 1 & 0 & 1 & 2 & 0 & 3 & 3 & 5 \\
\hline 7 & 3 & 0 & 2 & 2 & 2 & 5 & 5 & 2 & 1 & 4 & 4 & 4 & 2 & 4 \\
\hline 0 & 0 & 0 & 0 & 2 & 2 & 0 & 0 & 2 & 0 & 0 & 0 & 0 & 0 & 0 \\
\hline 5 & 1 & 0 & 0 & 0 & 0 & 0 & 0 & 0 & 0 & 0 & 0 & 4 & 0 & 0 \\
\hline 0 & 2 & 0 & 0 & 0 & 0 & 0 & 0 & 0 & 0 & 0 & 1 & 0 & 0 & 0 \\
\hline 0 & 0 & 0 & 0 & 0 & 0 & 0 & 0 & 0 & 0 & 0 & 0 & 0 & 0 & 0 \\
\hline 2 & 1 & 0 & 0 & 0 & 0 & 0 & 0 & 0 & 0 & 0 & 0 & 1 & 0 & 0 \\
\hline 0 & 0 & 0 & 0 & 0 & 0 & 2 & 5 & 0 & 0 & 0 & 0 & 0 & 0 & 0 \\
\hline 0 & 1 & 0 & 4 & 2 & 0 & 0 & 0 & 1 & 0 & 0 & 1 & 0 & 0 & 0 \\
\hline 0 & 0 & 0 & 0 & 0 & 1 & 1 & 0 & 0 & 0 & 0 & 0 & 0 & 1 & 0 \\
\hline 5 & 13 & 10 & 6 & 5 & 8 & 7 & 5 & 15 & 9 & 9 & 7 & 3 & 8 & 8 \\
\hline 1 & 1 & 2 & 3 & 4 & 4 & 6 & 1 & 2 & 3 & 2 & 3 & 0 & 0 & 2 \\
\hline 0 & 0 & 0 & 0 & 0 & 0 & 0 & 0 & 0 & 0 & 0 & 0 & 0 & 0 & 0 \\
\hline 1 & 0 & 0 & 0 & 2 & 0 & 0 & 5 & 0 & 0 & 1 & 0 & 2 & 0 & 0 \\
\hline 7 & 5 & 1 & 2 & 0 & 0 & 10 & 6 & 2 & 1 & 0 & 5 & 5 & 20 & 20 \\
\hline 1 & 4 & 13 & 14 & 4 & 5 & 1 & 4 & 4 & 3 & 8 & 5 & 0 & 5 & 2 \\
\hline 2 & 6 & 29 & 17 & 13 & 26 & 6 & 7 & 11 & 16 & 8 & 17 & 2 & 6 & 3 \\
\hline 3 & 11 & 42 & 30 & 18 & 31 & 7 & 10 & 15 & 19 & 17 & 22 & 2 & 12 & 5 \\
\hline 36874.77 & 9000.00 & 695.45 & 1205.56 & 2650.31 & 652.62 & 698.68 & 1725.91 & 213.43 & 340.00 & 1548.00 & 954.55 & 5961.29 & 71.15 & 2025.00 \\
\hline
\end{tabular}


APPENDIX II. Continued

\begin{tabular}{|c|c|c|c|c|c|c|c|c|c|c|c|c|}
\hline Dead $\%$ & $\mathrm{~T} 3 \mathrm{~S} 13$ & T3S15 & T3S 16 & $\mathrm{~T} 3 \mathrm{~S} 17$ & $\mathrm{~T} 3 \mathrm{~S}_{19}$ & $\mathrm{~T} 3 \mathrm{~S} 23$ & $\mathrm{~T} 6 \mathrm{~S} 02$ & $\mathrm{~T} 6 \mathrm{~S} 06$ & $\mathrm{~T} 6 \mathrm{~S} 08$ & $\mathrm{~T} 6 \mathrm{~S} 10$ & $\mathrm{~T} 6 \mathrm{~S} 12$ & T6S14 \\
\hline A. batavus & 2 & 4 & 3 & 1 & 2 & 3 & 0 & 5 & 3 & 2 & 1 & 1 \\
\hline A. wrighti & 0 & 0 & 0 & 0 & 1 & 0 & 0 & 0 & 0 & 0 & 0 & 0 \\
\hline A. mamilla & 0 & 0 & 0 & 0 & 0 & 0 & 0 & 0 & 1 & 1 & 0 & 0 \\
\hline B. gibba & 8 & 2 & 2 & 1 & 4 & 2 & 6 & 3 & 9 & 16 & 19 & 2 \\
\hline B. marginata & 5 & 27 & 14 & 24 & 19 & 15 & 0 & 0 & 0 & 2 & 5 & 24 \\
\hline B. pseudoplicata & 0 & 0 & 2 & 5 & 0 & 0 & 2 & 0 & 0 & 0 & 2 & 2 \\
\hline B. pseudopunctata & 0 & 0 & 0 & 0 & 0 & 0 & 2 & 0 & 0 & 0 & 0 & 0 \\
\hline B. variabulis & 0 & 0 & 0 & 0 & 0 & 0 & 0 & 0 & 0 & 0 & 0 & 0 \\
\hline Bolivina/Brizalina group & 0 & 1 & 3 & 5 & 0 & 1 & 4 & 0 & 0 & 0 & 2 & 3 \\
\hline C. lobatulus & 26 & 9 & 6 & 5 & 3 & 6 & 34 & 26 & 37 & 35 & 11 & 7 \\
\hline C. fletcheri & 1 & 0 & 2 & 0 & 0 & 0 & 0 & 0 & 0 & 0 & 3 & 0 \\
\hline C. obtusa & 3 & 2 & 2 & 2 & 0 & 0 & 0 & 0 & 0 & 0 & 2 & 1 \\
\hline \multicolumn{13}{|l|}{ E. excavatum forma } \\
\hline selseyensis & 2 & 0 & 0 & 1 & 0 & 0 & 2 & 0 & 0 & 0 & 0 & 0 \\
\hline E. gerthi & 0 & 1 & 1 & 0 & 0 & 0 & 0 & 0 & 0 & 0 & 1 & 0 \\
\hline E. magellanicum & 0 & 0 & 0 & 0 & 0 & 0 & 2 & 0 & 0 & 0 & 0 & 0 \\
\hline E. cf E. magellanicum & 0 & 0 & 0 & 0 & 0 & 0 & 2 & 0 & 0 & 0 & 0 & 0 \\
\hline E. repandus & 0 & 0 & 0 & 0 & 0 & 0 & 0 & 0 & 0 & 0 & 0 & 0 \\
\hline E. scaber & 0 & 0 & 0 & 0 & 0 & 2 & 0 & 0 & 1 & 2 & 0 & 0 \\
\hline E. vitrea & 2 & 0 & 4 & 5 & 0 & 1 & 1 & 0 & 0 & 0 & 2 & 3 \\
\hline G. praegeri & 2 & 9 & 7 & 10 & 4 & 3 & 1 & 0 & 2 & 0 & 9 & 9 \\
\hline G. rudis & 0 & 0 & 0 & 0 & 0 & 0 & 0 & 0 & 0 & 0 & 0 & 0 \\
\hline H. balthica & 0 & 0 & 0 & 0 & 11 & 9 & 0 & 0 & 0 & 0 & 0 & 2 \\
\hline M. subrotunda & 0 & 0 & 0 & 0 & 0 & 0 & 3 & 0 & 0 & 0 & 0 & 0 \\
\hline N. depressulus & 0 & 0 & 0 & 0 & 0 & 0 & 0 & 0 & 0 & 0 & 0 & 0 \\
\hline N. turgida & 0 & 1 & 1 & 1 & 1 & 1 & 0 & 0 & 0 & 0 & 0 & 2 \\
\hline O. balkwilli & 0 & 0 & 0 & 0 & 0 & 0 & 0 & 0 & 0 & 0 & 0 & 0 \\
\hline P. depressa & 0 & 0 & 0 & 0 & 0 & 0 & 0 & 0 & 0 & 0 & 0 & 0 \\
\hline$P$. distoma & 3 & 3 & 0 & 6 & 0 & 0 & 0 & 0 & 1 & 0 & 0 & 0 \\
\hline Q. seminulum & 7 & 6 & 3 & 3 & 6 & 2 & 0 & 15 & 8 & 18 & 4 & 0 \\
\hline R. bradyi & 1 & 0 & 0 & 0 & 0 & 0 & 1 & 1 & 0 & 0 & 0 & 0 \\
\hline R. anomala & 0 & 0 & 0 & 0 & 0 & 0 & 6 & 0 & 0 & 0 & 0 & 0 \\
\hline R. williamsoni & 0 & 0 & 1 & 0 & 0 & 0 & 0 & 0 & 0 & 0 & 0 & 0 \\
\hline S. fusiformis & 11 & 6 & 29 & 15 & 6 & 4 & 2 & 1 & 1 & 0 & 10 & 14 \\
\hline S. wrightii & 2 & 5 & 2 & 0 & 20 & 23 & 4 & 13 & 12 & 6 & 3 & 4 \\
\hline T. bockü & 13 & 11 & 10 & 11 & 14 & 17 & 13 & 22 & 15 & 10 & 17 & 13 \\
\hline Textilina group & 16 & 16 & 12 & 11 & 34 & 40 & 17 & 35 & 27 & 17 & 20 & 17 \\
\hline Density per $10 \mathrm{~cm}^{3}$ & 5070.59 & 4311.27 & 8460.00 & 8131.76 & 2209.09 & 3090.00 & 267.00 & 52.95 & 357.86 & 910.08 & 2340.00 & 4032.00 \\
\hline
\end{tabular}


BENTHIC FORAMINIFERA AND SEASONAL STRA TIFICA TION

APPENDIX II. Continued, Extended.

\begin{tabular}{|c|c|c|c|c|c|c|c|c|c|c|c|c|c|c|}
\hline T6S 16 & $\mathrm{~T} 7 \mathrm{~S} 02$ & $\mathrm{~T} 7 \mathrm{~S} 06$ & $\mathrm{~T} 7 \mathrm{~S} 10$ & T7S 16 & $\mathrm{~T} 8 \mathrm{~S} 01$ & $\mathrm{~T} 8 \mathrm{~S} 02$ & T8S05 & T8SOS & TSSO9 & T8S 10 & T8S 13 & T8S 16 & T8S 20 & T8S21 \\
\hline 1 & 4 & 7 & 3 & 2 & 0 & 1 & 2 & 3 & 5 & 3 & 4 & 4 & 5 & 4 \\
\hline 0 & 0 & 0 & 1 & 0 & 0 & 0 & 0 & 0 & 0 & 0 & 0 & 0 & 0 & 0 \\
\hline 0 & 1 & 3 & 0 & 0 & 0 & 0 & 0 & 0 & 0 & 0 & 0 & 0 & 0 & 0 \\
\hline 2 & 3 & 2 & 4 & 0 & 1 & 2 & 26 & 60 & 42 & 42 & 28 & 8 & 12 & 5 \\
\hline 24 & 0 & 0 & 9 & 47 & 4 & 5 & 0 & 0 & 0 & 0 & 0 & 0 & 0 & 0 \\
\hline 2 & & 0 & 0 & 0 & 1 & 5 & 3 & 0 & 0 & 0 & 0 & 3 & 2 & 0 \\
\hline 0 & 0 & 0 & 0 & 0 & 2 & 0 & 0 & 0 & 0 & 0 & 0 & 0 & 0 & 0 \\
\hline 0 & 0 & 0 & 0 & 0 & 7 & 0 & 0 & 0 & 0 & 0 & 0 & 0 & 1 & 2 \\
\hline 3 & 0 & 0 & 2 & 2 & 13 & 9 & 5 & 0 & 0 & 0 & 0 & 4 & 4 & 2 \\
\hline 7 & 24 & 22 & 24 & 0 & 2 & 2 & 6 & 2 & 6 & 5 & 4 & 8 & 12 & 7 \\
\hline 0 & 2 & 0 & 1 & 0 & 6 & 4 & 3 & 2 & 2 & 2 & 0 & 2 & 2 & 4 \\
\hline 1 & 1 & 0 & 0 & 1 & 5 & 7 & 0 & 0 & 0 & 0 & 0 & 1 & 0 & 0 \\
\hline 0 & 3 & 1 & 1 & 0 & 0 & 2 & 0 & 9 & 3 & 5 & 14 & 23 & 15 & 4 \\
\hline 0 & 0 & 0 & 3 & 0 & 2 & 2 & 4 & 1 & 1 & 0 & 2 & 2 & 3 & 4 \\
\hline 0 & 0 & 0 & 0 & 0 & 1 & 0 & 1 & 0 & 0 & 0 & 1 & 3 & 0 & 4 \\
\hline 0 & 2 & 0 & 0 & 0 & 0 & 0 & 0 & 0 & 0 & 0 & 0 & 5 & 3 & 0 \\
\hline 0 & 3 & 0 & 0 & 0 & 0 & 0 & 0 & 0 & 0 & 0 & 0 & 0 & 0 & 0 \\
\hline 0 & 0 & 0 & 0 & 2 & 0 & 2 & 0 & 0 & 3 & 4 & 12 & 4 & 2 & 1 \\
\hline 3 & 0 & 0 & 1 & 1 & 5 & 4 & 0 & 0 & 0 & 0 & 0 & 0 & 0 & 0 \\
\hline 9 & 5 & 3 & 5 & 0 & 9 & 7 & 8 & 2 & 0 & 0 & 2 & 5 & 4 & 3 \\
\hline 0 & 3 & 0 & 0 & 0 & 0 & 0 & 0 & 0 & 0 & 0 & 0 & 0 & 0 & 0 \\
\hline 2 & 0 & 0 & 0 & 15 & 0 & 5 & 0 & 0 & 0 & 0 & 0 & 0 & 0 & 0 \\
\hline 0 & 0 & 1 & 2 & 0 & 2 & 2 & 2 & 0 & 1 & 0 & 0 & 0 & 2 & 3 \\
\hline 0 & 0 & 1 & 1 & 0 & 1 & 0 & 3 & 0 & 0 & 0 & 0 & 1 & 2 & 2 \\
\hline 2 & 0 & 0 & 0 & 0 & 1 & 1 & 0 & 0 & 0 & 0 & 0 & 0 & 0 & 0 \\
\hline 0 & 0 & 0 & 0 & 0 & 0 & 0 & 0 & 0 & 0 & 0 & 0 & 0 & 0 & 0 \\
\hline 0 & 0 & 4 & 0 & 0 & 0 & 0 & 0 & 0 & 0 & 0 & 0 & 0 & 0 & 0 \\
\hline 0 & 0 & 0 & 0 & 0 & 0 & 1 & 3 & 0 & 1 & 0 & 0 & 0 & 0 & 0 \\
\hline 0 & 16 & 7 & 10 & 11 & 2 & 5 & 6 & 7 & 23 & 17 & 12 & 7 & 8 & 4 \\
\hline 0 & 6 & 3 & 2 & 0 & 1 & 0 & 2 & 0 & 0 & 0 & 0 & 0 & 1 & 0 \\
\hline 0 & 0 & 0 & 0 & 0 & 3 & 0 & 1 & 0 & 0 & 0 & 0 & 1 & 4 & 2 \\
\hline 0 & 0 & 0 & 0 & 0 & 2 & 0 & 0 & 0 & 0 & 0 & 0 & 0 & 0 & 0 \\
\hline 14 & 0 & 0 & 4 & 0 & 14 & 13 & 3 & 0 & 0 & 0 & 0 & 2 & 0 & 2 \\
\hline 4 & 3 & 14 & 3 & 1 & 0 & 0 & 3 & 0 & 1 & 0 & 0 & 2 & 1 & 0 \\
\hline 13 & 9 & 19 & 9 & 3 & 3 & 1 & 4 & 4 & 9 & 12 & 13 & 4 & 3 & 4 \\
\hline 17 & 12 & 32 & 12 & 5 & 3 & 2 & 7 & 5 & 10 & 13 & 14 & 6 & 4 & 4 \\
\hline 5253.33 & 447.27 & 3810.00 & 4142.12 & 5578.67 & 33660.00 & 26067.69 & 8905.26 & 3881.25 & 4352.73 & 866.25 & 913.50 & 3272.73 & 451.38 & 7560.00 \\
\hline
\end{tabular}




\section{APPENDIX III. ENVIRONMENTAL AND TAXONOMIC NOTES ON INDIVIDUAL SPECIES}

Ammonia batavus (Fig. 6a,b) constitutes a similar proportion of both live and dead assemblages, though the distributions are quite different. The largest live contribution of this species is found in the central part of the area and to the north It is particularly concentrated in the stratified area to the southwest, but is completely absent from parts of the west and transect 8 . Dead A. batavus is most abundant in the north and along transect 8 . Correlation of the dead distribution with grain size and skewness, combined with the robust nature of the test, suggests that reworking is probable. Both live and dead individuals of A. batavus inhabit northerly sites and high $\%$ grave 1 according to the CCA. The live distribution is also related to temperature and the dead to mean grain size and skewness. A. batavus can tolerate great vari ability in temperature, salinity, and oxygen (Lutze, 1965; R isda1 1964), which helps explain the live distribution.

Adercotryma wrighti was first identified in this study as A. glomeratum, but following the recent re-evaluation of Celtic Sea samples by Murray (2000), re-identified as $A$. wrighti; Brönnimann and Whittaker (1987) have distinguished between A. glomeratum (four chambers in the final whorl, three vis ible on each side), and $A$. wrighti (three chambers in the final whorl three seen on the apertural and two on the antapertura1 side). It is probable that, in temperate waters, $A$. wright $i$ has been misidentified as $A$. glomeratum. A. glomeratum is offen considered an Arctic indicator, and its distribution was interpreted by Williamson and others (1984) to correlate with lower temperatures. How ever, the recent consensus is that neither temperature nor substrate are the main controls (Alve and Nagy, 1986; Christiansen, 1958; L eslie, 1965; Schafer and Cole, 1974; Thiede and others, 1981), and it is probable that these subsequent studies relate to $A$. wright $i$ rather than to $A$. glomeratum.

A. wrighti (F ig. 6c,d) is distributed similarly in both live and dead assemblages but there is a large difference in the relative contribution made to each. Live $A$. wrighti can constitute as much as $10 \%$ of the total live assemblage, but dead it rarely exceeds $1 \%$. There is a strong association between live occurrences of this species and stratified and frontal waters. CCA shows that the live and dead distributions of $A$. wrighti are related to cold water temperatures; live occurrences also associate with longitude, while the dead correlate with skewness. The increase in dead abundance along a skewness gradient indicates either reworking or long-term accumulation of tests pointing to an association with these conditions. A number of studies indicate that this species not only prefers high carbon flux, but can also to lerate the low oxygen levels offen associated with such conditions (A lve and Nagy, 1986; Gooday, 1993; Austin and Sejrup, 1994). This is confirmed by Bernhard and Alve (1996), who concluded from nitrogen incubation experiments that the species is a facultative anaerobe, able to survive phases of anoxia, possibly by becoming dormant. These data suggest that the species is an opportunistic species; its small size is certainly appropriate to such a life strategy.

$\mathrm{L}$ ive and dead distributions of $B$ ulimina gibba (Fig. $6 \mathrm{e}, \mathrm{f})$ are similar It is most abundant to the south and west but, most significantly, along transect 8 where it constitutes about a fifth of the live and dead assemblages. CCA shows a relationship between this species and coarser substrates with high $\%$ sand content. Though Bulimina spp. are widely regarded as low-oxygen tolerant (Sen Gupta and Machain-Castillo, 1993), B. gibba is not abundant in those parts of the Celtic Sea assumed to be oxygen deficient (i.e., under stratified waters). It is rare or absent from the Celtic Deep basin. However, $B$. gibba appears to replace $B$. marginata in stratified samples in the west and east where the substrate is relatively coarse. This suggests that while $B$. gibba may be tolerant of low levels of oxygen depletion, its lower threshold levels are higher than for B. marginata, and so it is restricted to sandier substrates where infaunal oxygen levels are higher.

$L$ ive and dead specimens of Bulimina marginata also show similar distribution patterns, though this species constitutes a far greater proportion of the dead assemblage than the live ( F ig. 6g,h). Both distri butions reflect the area of stratified and frontal waters, except along the entrance to the Bristo1 Channel where this species is rare or absent In fully stratified waters, $B$. marginata is usually dominant in the dead assemblage. Interestingly, the position of the pervasive intrusion of stratified waters into the northem Celtic Deep trough is reflected in the distribution of this species. A relationship between $B$. marginata and depth is identified in both live and dead distributions by CCA. The live also show a relationship with temperature, hence stratification, and longitude. The dead are enriched in sites skewed towards fines, possibly the result of rew orking. Though a large number of studies demonstrate that $B$. marginata prefers high organic fluxes and is able to tolerate low oxygen levels (Bandy and others, 1965; Risda1 1963; SenGupta and Machain-Castillo, 1993), in their experiments to test the response of various species to anoxia events through nitrogen incubation, Bernhard and A ve (1996) found that B. marginata had a poor survival rate. Other studies have drawn attention to the affinity of $B$. marginata for specific substrates (cf. Conradsen, 1993; Conradsen and others, 1994; Murray, 1986). This relationship probably derives from the fact that as organic content increases, grain size often becomes finer (Cato, 1977). Further evidence that B. marginata is associated with high level of organic carbon is provided by Conradsen (1993), Conradsen and others (1994), and Qvale and van Weering (1985). B. marginata has also been reported from the stratified waters of the northern North Sea (Klitgaard-Kristensen and Sejrup, 1996).

Cibicides lobatulus never constitutes more than around $10 \%$ of the live assemblage but accounts for up to $20 \%$ of the dead at some sites (Fig. 6ij). The distribution of live and dead C. lobatulus is the inverse of $B$. marginata, being highest in mixed and frontal waters. High values shift westward for the dead relative to the live, while dead vahes do not increase to the south as they do for the live. The contribution of C. lobatulus is least for sites along transect 8 and in the southern half of the area. CCA shows that both live and dead C. lobatulus are most abundant in the north, in warmer waters, and, for the dead only, in areas of high $\%$ gravel As stratification is directly related to temperature, and the more northerly sites in this study are those which are mixed, this confirms $C$. lobatulus as a mixed assemblage indicator This conclusion is supported by the almost complete consensus in the literature on the ecological preference of this largely epilithic species for fully oxygenated, high energy conditions and coarse-grained sedi ments (Murray, 1971; Conradsen, 1993; Hald and Steinsund, 1992. Klitgaard-Kristensen and Sejrup, 1996; Mackensen and others, 1985)

Eggerelloides scaber: CCA detected a strong relationship between this species and \% sand. A relationship with mean grain size and skewness was also indicated for the dead assemblage, implicating reworking. Despite the grain size relationship, there is some evidence to suggest that substrate type is not the controlling variable. Murray (1986) reports it living in muddy sediments in Lyme Bay, and Alve and Nagy (1986) found it living in both coarse and fine-grained sediments in the Sandebukta branch of the Oslofjord. The latter authors found it tolerant of both high organic input and wood fibre pollhtion in Sandebukta, and suggest that its abundance might be related to low competition Conradsen (1993) and Conradsen and others (1994) also find that it correlates positively with the organic content of sediments in the Kattegat and Skaggerak. In the Drammensfjord, Norway, it occurs in transitional waters between brackish and oxygen-depleted, suggesting that it is tolerant of moderately low oxygen concentrations. It is also found in the seasonally stratified waters of Breidangen, Oslofjord (A ve and Nagy, 1990) and close to a front in the Kattegat-Skaggerak (Conradsen and others, 1994). Lutze (1965) suggested that E. scaber is tolerant of temperature, salinity, and current variability, having found it living in the inflowing waters of the Danish Straits. De Stigter and others (1998) conchde that $E$. scaber is tolerant of low oxygen conditions but also suggest that it is a non-specific feeder. $E$. scaber probably has a poorer tolerance of low oxygen concentrations than some opportunists, but has compensated by developing an ability to withstand fluctuations in temperature, salinity, current velocity, and food supply explaining its abundance along the entrance of the Bristo1 Channe1

The live and dead distributions of Gavelinopsis praegeri are the inverse of each other (F ig. 6k,1). It is most abundant live in the mixed waters to the north and in the fully stratified waters away from the front, but dead it is most abundant in the transition between frontal and stratified waters and to the northeast. Live individuals are rare or absent along transect 8 but here dead specimens can contribute as much as $6 \%$ of some assemblages.

Live tests of Hyalinea balthica never account for more than $4.5 \%$ of the living assemblages but are well represented in the dead, where they can constitute as much as $17 \%$ of the total $(\mathrm{F}$ ig. $6 \mathrm{~m}, \mathrm{n})$. Both distributions reflect the extent of stratified and mixed waters, except along the entrance to the Bristo1Channe1 CCA confirms that both live and dead distributions are related to temperature and hence stratification. The contours are much tighter for the dead, and abundance in- 
creases evenly in a southwest direction, while the live are slightly more abundant in the west than in the frontal region. As with $B$. marginata the distribution reflects the pervasive intrusion of stratified waters into the Celtic Deep trough. This feature is also reflected in the distribution of both living and dead $N$. turgida which, like $B$. marginata and $H$. balthica, also shows an affinity for stratified and frontal waters (Fig. $60, p)$. Similarly, $N$. turgida is also rare or absent from the entrance to the Bristo1 Channe1 Qvale and van Weering (1985) report an association between $H$. balthic $a$ and high sediment organic content, and Sen Gupta and Machain-Castillo (1993) found the species abundant in oxygen minimum zones, both parameters associated with stratification Though the abundance data on other bloom species, such as $S$. fus $i$ formis, indicate that the flux of organic matter and oxygen concentrations are variable across the frontalregion, this species shows a gradual and steady increase into stratified waters and records the area covered by the persistent eddy. So while it may tolerate low oxygen and prefer high organic flux, the precise environmental controls on this species are unclear, though the distributional data suggest factors linked to stratification.

Nonionella turgida: the strong similarity between the live and dead distributions of $N$. turgida suggest that this species is not eas ily reworked despite its poor representation in the dead ( F ig. 6o,p). Thi may result from its infaunal occurrence in mainly muddy sediments (J.W.Murray, personal communication, 2000). The abundance of this species in the dead assemblage was too low to include in the CCA but the same analys is of the live data places the optimum occurrence of this species in the relatively colder, deeper, stratified waters in the south characterized by fine-grained sediments. This is supported by Conradsen (1993), who found $N$. turgida living in association with $B$ marginata in fine-grained, high organic carbon sites. Though this suggests that this species may be tolerant of high carbon fluxes, Bandy and others (1965) reported that pollution from the Hyperion sewage outfall in Califormia affected the Nonionella group unfavourably. Nevertheless, the distribution of $N$. turgida is strongly as sociated with stratification, demonstrating the potential significance of rarer species as paleostratifration indicators.

Quinqueloculina seminulum makes important contributions to both live and dead assemblages in the Celtic Sea, but is more abundant in the dead. The highest live occurrences are in the east while the dead are concentrated in the frontal and mixed areas to the north and along the Bris to 1 Channelentrance (F ig. $6 \mathrm{q}, \mathrm{r})$. The stratified intrus ion is again highlighted by a positive anomaly in the live distribution. CCA relates maximaloccurrences of dead $Q$. seminulum to shallower, warmer, sites, while the live are associated with high sand content in shallower sites. Despite the large dead/live distributional differences, the dead specimens show no relationship with sorting or skewness, suggesting that reworking is unlikely. Buzas (1993) describes $Q$. seminulum as an opportunist based on an in situ experiment in a shallow site in which $Q$. seminulum was the first species to recolonize following disturbance. Murray (1991) describes it as a phytodetrital feeder. It is therefore possible that this species, like $A$. batavus, can tolerate a wide range of conditions.

The distributions of Spiroplectammina wrightii and Textularia bockii are very similar ( $\mathrm{F}$ ig. $6 \mathrm{u}-\mathrm{x})$, and it has been suggested that these species should be humped together (Murray, 1979). Both contribute significantly to the dead assemblage but are less well represented in the live. This may be the result of the dense agghtinated tests obscuring the pink staining of live individuals. How ever, despite the low numbers of live specimens identified, the distribution seems comparable to the dead; the species is abundant in the north in mixed and frontal waters but also in the south in fully stratified waters well away from the frontal region. Numbers are low for the intermediate area and along the entrance to the Bristo1 Channe1 CCA shows that both live S. wrightii and $T$. bockii inhabit warmer sites with coarser sediments. They are found dead in the shallower sites in well-sorted sediments. Some post-mortem transport is plausible given their epifaunal habitat (Murray, 1991). Murray (1986) observed T. bockii living in shelly sand, and Klitgaard-Kristensen and Sejrup (1996) found it living in coarse-grained sediments associated with strong currents in the northern North Sea. Conradsen (1993) defined an assemblage consisting of $T$. bockii with $C$. lobatulus and $G$. praegeri, which correlated with coarse grain sizes. It seems likely that these species distributions, when living, are related to coarser sediments as might be expected given their epiphytic/epilithic life-strategy (Murray, 1991; Vilks and Deonarine, 1987). However, other unknown variables must also be influential since they do not thrive in similar substrates along the entrance to the Bristo1 Channe1

\section{APPENDIX IV. DETAILS OF FACTOR ANALYSIS RESULTS} LIVE DATA

The first four live factors account for over $80 \%$ of the variance. The most important of these is defined by the Textilina group (0.98), Reophax group $(-0.97)$, and $S$. fusiform is $(-0.86)$. The latter two are negatively correlated to this factor, so that where the Q-mode scores are most negative these species are most significant. Live factor 1 is therefore most significant in the frontal-stratified zone, along much of transect 8 , and in parts of the mixed area (Fig. 7a). This is the most significant of the live assemblages and accounts for $58 \%$ of the variance in the data

The second live factor assemblage accounts for $11 \%$ of the variance and is defined by $G$. praegeri $(0.74)$. G. pygmaeus $(0.67)$, and $C$. lobatulus $(0.62)$ are subdominant. These species are positively correlated to factor 2, so the most positive Q-mode scores indicate where this assemblage is most important. The area of dominance is located in the mixed and mixed/frontal zones ( F ig. $7 \mathrm{~b}$ ), but also in the fully stratified waters to the south. This assemblage is not significant along transect 8 . This factor has a negative correlation $\left(R^{2}=0.44\right)$ with $\Phi$ indicating that this factor is associated with coarser sediments

$B$. marginata $(-0.71)$ is the defning species of live factor assemblage 3 , with $A$. wrighti $(-0.61)$ and $N$. turgida $(-0.49)$ subdominant. These species are negatively correlated with factor 3 , and are therefore dominant in the stratified and stratified-frontal waters in the center of the area, but absent along the entrance to the Bristo1 Channe1(Fig. 7c) This assemblage accounts for just $7.7 \%$ of the variance, but correlates with several environmental variables, inchding bottom water temperature $\left(R^{2}=0.532\right)$, salinity $\left(R^{2}=0.338\right)$ and $S$-index $\left(R^{2}=0.676\right)$ As the dominant species are negatively correlated to the Q-mode scores, these correlations indicate that this assemblage is most significant at southerly stratified sites characterized by relatively lower temperatures and higher salinities.

The fourth factor assemblage accounts for just $4.5 \%$ of the variance, but does not correlate with any of the environmental variables. The defining species, E. scaber, is negatively related to the factor $(-0.39)$. This assemblage is most abundant along transect 8 and in the south of the area $(\mathrm{Fig}$. $7 \mathrm{~d})$.

\section{DEAD DATA}

The defining species of the most significant of the dead assemblages, accounting for over $58 \%$ of the variance, is $Q$. seminulum $(-1.66)$, with Textilina group $(-1.27), A$. batavus $(-1.2)$ and $C$. lobatulus $(-1.12)$ subdominant. These species are most important in the mixed and mixed-frontal region ( F ig. 8a), but exchuding the area of pervasive stratification in the northem Celtic Deep. There are no significant correlations between this factor and any of the measured environmental variables.

Dead factor assemblage 2 , which accounts for $13 \%$ of the variance, is defined by $H$. balthica $(0.63)$ with subdominant $B$. marginata $(0.56)$, G. praegeri $(0.53)$ and Bolivina group $(0.54)$. This assemblage domi nates in stratified waters, including the northern Celtic Deep ( $F$ ig. $8 b$ ), and correlates with a number of environmental variables, including temperature $\left(R^{2}=0.396\right), \%$ clay $\left(R^{2}=0.483\right)$ and mean grain size $\left(\mathrm{R}^{2}=0.331\right)$. As this assemblage is positively related to the $\mathrm{Q}$-mode factor scores, this indicates that it is most important in cooler sites characterised by fine sediments and high \% silt content.

E. magellanicum $(0.51)$ characterizes dead factor assemblage 3 , along with $E$. excavatum forma selseyens is $(0.25)$ and Bolivina group (0.27). This assemblage explains over $7 \%$ of the variance and, as it is positively correlated to the Q-mode scores, is prominent along most of transect 8 and in the mixed area to the north (Fig. 8c). There were no significant correlations between this assemblage and any of the measured environmental variables.

Dead factor assemblage 4 accounts for $5.8 \%$ of the variance and is characterized by $E$. scaber $(0.49)$, with subdominant $B$. gibba $(0.47)$ and $Q$. seminulum $(0.44)$. This assemblage is positively related to the $\mathrm{Q}$-mode scores and is most sionificant in the eastern part of the area (Fig. 8d) 
APPENDIX V. Results of the CCA on the live foraminiferal and the environmental data.

\begin{tabular}{|c|c|c|c|c|}
\hline Live CCA Scores & Axis 1 & Axis 2 & Axis 3 & Axis 4 \\
\hline Ammonia batavus & 0.44 & -0.19 & 0.23 & 0.28 \\
\hline Adercotryma wrighti & -0.02 & -0.53 & 0.76 & 0.3 \\
\hline Bulimina gibba & -0.26 & 1.23 & 0.53 & -0.21 \\
\hline Bulimmina marginata & -0.04 & -0.63 & 0.78 & 0.24 \\
\hline Bolivina pseudoplicata & 1.16 & 0.3 & -0.25 & 0 \\
\hline Bolivinellina pseudopunctata & 0.42 & -0.27 & -0.06 & 0.3 \\
\hline Brizalina variabilis & 0.42 & 1.81 & 0.22 & 0.51 \\
\hline Cibicides fletcheri & 1.61 & 0 & -0.49 & 0.22 \\
\hline Cibicides lobatulus & 0.99 & 0.34 & -0.43 & -0.11 \\
\hline Cancris auricula & 0.72 & -0.35 & 0.05 & 0.28 \\
\hline Discorbinella $\mathrm{sp}$. & 0.5 & 0.78 & 0 & -1.09 \\
\hline Egerella advena & 0.3 & -0.25 & 0.46 & -0.03 \\
\hline Elphidium excavatum forma selseyensis & -0.58 & 2.04 & -0.24 & 1.49 \\
\hline Elphidium gerthi & -0.5 & 2.27 & -1.43 & 1.24 \\
\hline Elphidium magellanicum & 0.97 & 0.33 & -0.66 & -0.05 \\
\hline Elphidium $\mathrm{cf} E$. magellanicum & 0.98 & 1.19 & -0.54 & -0.25 \\
\hline Eggerelloides scaber & -0.66 & 0.84 & 0.69 & -0.25 \\
\hline Ep istominella vitrea & 0.06 & -0.31 & 0.65 & 0.19 \\
\hline Fissurina lucida & 0.98 & 0 & -0.65 & -0.97 \\
\hline Fissurina marginata & 1.54 & 0.56 & -0.7 & -0.4 \\
\hline Hyalina balthica & -0.21 & -0.29 & 0.41 & 0.28 \\
\hline Haplophragmoides bradyi & 0.33 & -0.72 & 0.64 & 0.18 \\
\hline Haplophragmoides fragile & 0.77 & -0.5 & 0.83 & -0.17 \\
\hline Lamarkina haliotidea & 0.89 & 1.06 & -0.21 & 0.12 \\
\hline Miliolinella subrotunda & 1.04 & 0.67 & -0.6 & 0.14 \\
\hline Nonionella auricula & 0.18 & -0.47 & 0.19 & 0.67 \\
\hline Nonionella turgida & -0.45 & -0.69 & 0.02 & 0.28 \\
\hline Ophthalmidium balkwilli & 1.59 & -0.26 & -0.53 & 0.41 \\
\hline Quinqueloculina seminulum & 0.01 & 0.23 & 0.23 & -0.36 \\
\hline Rosalina bradyi & 1.02 & 0.03 & -0.41 & -0.03 \\
\hline Rosalina fusiformis & 0.31 & -0.27 & 0.63 & -0.55 \\
\hline Gavelinopsis praegeri & 0.98 & 0.14 & 0 & -0.09 \\
\hline Reaphax scorpiurus & -0.59 & -0.24 & 0.23 & -0.06 \\
\hline Stainfor thia fusiform is & -0.35 & -0.11 & -0.24 & -0.08 \\
\hline Spirillina vivịara & 2.24 & 0.25 & -0.1 & 0.17 \\
\hline Spiroplectammina wrightï & 0.3 & 0.42 & 0.13 & -0.47 \\
\hline Textularia bockï & 1.08 & 0.46 & -0.16 & -0.19 \\
\hline Globotrochamminopsis pygmaeus & 0.7 & -0.31 & 0.28 & -0.15 \\
\hline Deuterammina (Lepidodeuterammina) ochracea & 1.28 & 0.07 & -0.24 & -0.01 \\
\hline Depth & 0.04 & -0.84 & 0.09 & -0.22 \\
\hline Temperature & 0.52 & 0.69 & -0.41 & -0.08 \\
\hline$\%$ grave 1 & 0.75 & 0 & -0.36 & -0.06 \\
\hline$\%$ sand & -0.06 & 0.32 & 0.43 & -0.29 \\
\hline Mean grain size & -0.85 & -0.19 & -0.1 & -0.05 \\
\hline Sorting (moments) & -0.07 & -0.18 & -0.59 & 0.49 \\
\hline Skewness (moments) & -0.53 & -0.13 & -0.09 & -0.05 \\
\hline Skewness (folks) & -0.42 & -0.1 & -0.2 & 0.05 \\
\hline Kurtos is (moments) & -0.26 & 0.12 & 0 & -0.24 \\
\hline Kurtos is (folks) & -0.43 & 0.03 & -0.15 & 0.06 \\
\hline Latitude & 0.6 & 0.09 & -0.49 & -0.14 \\
\hline Longitude & -0.01 & -0.7 & 0.1 & -0.28 \\
\hline
\end{tabular}


APPENDIX VI. Results of the CCA on the dead foraminiferal and the environmental data.

\begin{tabular}{|c|c|c|c|c|}
\hline Dead CCA Scores & Axis 1 & Axis 2 & Axis 3 & Axis 4 \\
\hline Ammonia batavus & 0.01 & -0.18 & -0.05 & -0.07 \\
\hline Adercotryma wrighti & -0.63 & 0.44 & 0.09 & 0.43 \\
\hline Asterigerinata mamilla & -0.2 & -0.52 & -0.34 & 0.24 \\
\hline Bulimina gibba & 0.82 & 0.73 & -0.36 & 0.28 \\
\hline Bulimina marginata & -0.69 & 0.56 & 0.08 & -0.18 \\
\hline Bolivina pseudoplicata & -0.22 & -0.12 & 0.54 & 0.19 \\
\hline Bolivinellina pseudopunctata & -0.3 & -0.44 & 0.68 & 0.14 \\
\hline Brizalina variabilis & -0.05 & -0.32 & 1.12 & 0.58 \\
\hline Cibicides lobatulus & 0.02 & -0.5 & -0.28 & 0.03 \\
\hline Cibicides fletcheri & 0 & -0.24 & 0.44 & 0.14 \\
\hline Cassidulina obtusa & -0.52 & 0.14 & 0.78 & 0.42 \\
\hline Elphidium excavatum forma selseyens is & 1.47 & -0.02 & 0.88 & -0.57 \\
\hline Elphidium gerthi & 0.38 & -0.12 & 0.37 & 0.13 \\
\hline Elphidium magellanicum & 1.04 & -0.85 & 0.8 & -0.36 \\
\hline Elphidium cf E. magellanicum & 0.5 & -0.87 & 0.45 & -0.34 \\
\hline Eponides repandus & 0.11 & -1.16 & -0.72 & 0.59 \\
\hline Eggerelloides scaber & 0.59 & 0.78 & 0.21 & -0.46 \\
\hline Ep istom inella vïtrea & -0.59 & 0.11 & 0.73 & 0.28 \\
\hline Gavelinopsis praegeri & -0.21 & 0.16 & 0.42 & 0.15 \\
\hline Gaudyrina rudis & -0.17 & -1.13 & -0.47 & 0.11 \\
\hline Hyalina balthica & -0.86 & 0.74 & -0.01 & -0.36 \\
\hline Miliolinella subrotunda & 0.4 & 0 & 0.35 & 0.08 \\
\hline Nonion depressulus & 0.63 & 0.06 & 0.75 & -0.03 \\
\hline Ophthalmidium balkwilli & 0.32 & -1.21 & 0.79 & 0.08 \\
\hline Pyrgo depressa & -0.5 & -0.73 & -0.47 & -0.05 \\
\hline Planorbulina distoma & 0.19 & -0.16 & -0.08 & 0.18 \\
\hline Quinqueloculina seminulum & 0.19 & -0.05 & -0.18 & 0.08 \\
\hline Rosalina bradyi & -0.14 & -0.62 & -0.04 & 0.06 \\
\hline Rosalina anomala & 0.99 & -0.42 & 0.74 & 0.1 \\
\hline Rosalina williamsoni & -0.4 & -0.44 & 0.68 & 0.22 \\
\hline Stainforthia fusiform is & -0.45 & 0.02 & 0.47 & 0.15 \\
\hline Spiroplectammina wrightï & -0.33 & -0.01 & -0.43 & -0.21 \\
\hline Textularia bockï & -0.09 & -0.07 & -0.3 & -0.16 \\
\hline Depth & -0.83 & -0.02 & -0.1 & 0.28 \\
\hline Temperature & 0.69 & 0.56 & 0 & -0.02 \\
\hline$\%$ grave 1 & 0.03 & -0.69 & -0.08 & 0.03 \\
\hline$\%$ sand & 0.24 & 0.27 & -0.65 & -0.38 \\
\hline Mean grain size & -0.12 & 0.57 & 0.45 & 0.37 \\
\hline Sorting (moments) & -0.18 & -0.23 & 0.67 & -0.09 \\
\hline Skewness (moments) & 0.02 & 0.41 & 0.08 & 0.41 \\
\hline Skewness (folks) & -0.07 & 0.16 & 0.18 & 0.04 \\
\hline Kurtosis (moments) & 0.24 & 0.34 & -0.19 & 0.4 \\
\hline Kurtos is (folks) & 0.08 & 0.14 & 0.23 & 0.05 \\
\hline Latinde & 0.13 & -0.87 & -0.27 & -0.02 \\
\hline Longitude & -0.68 & 0.16 & -0.42 & 0.25 \\
\hline
\end{tabular}

